\title{
A quantification method for heat-decomposable methylglyoxal oligomers and its application on 1,3,5-trimethylbenzene SOA
}

\author{
Maria Rodigast, Anke Mutzel, and Hartmut Herrmann \\ Leibniz Institute for Tropospheric Research (TROPOS), Atmospheric Chemistry Dept. (ACD), Permoserstr. 15, \\ 04318 Leipzig, Germany
}

Correspondence to: Hartmut Herrmann (herrmann@ tropos.de)

Received: 2 July 2016 - Discussion started: 10 August 2016

Revised: 22 February 2017 - Accepted: 27 February 2017 - Published: 23 March 2017

\begin{abstract}
Methylglyoxal forms oligomeric compounds in the atmospheric aqueous particle phase, which could establish a significant contribution to the formation of aqueous secondary organic aerosol (aqSOA). Thus far, no suitable method for the quantification of methylglyoxal oligomers is available despite the great effort spent for structure elucidation. In the present study a simplified method was developed to quantify heat-decomposable methylglyoxal oligomers as a sum parameter. The method is based on the thermal decomposition of oligomers into methylglyoxal monomers. Formed methylglyoxal monomers were detected using PFBHA (o(2,3,4,5,6-pentafluorobenzyl)hydroxylamine hydrochloride) derivatisation and gas chromatography-mass spectrometry (GC/MS) analysis. The method development was focused on the heating time (varied between 15 and $48 \mathrm{~h}$ ), $\mathrm{pH}$ during the heating process $(\mathrm{pH}=1-7)$, and heating temperature $\left(50,100^{\circ} \mathrm{C}\right)$. The optimised values of these method parameters are presented.

The developed method was applied to quantify heatdecomposable methylglyoxal oligomers formed during the OH-radical oxidation of 1,3,5-trimethylbenzene (TMB) in the Leipzig aerosol chamber (LEipziger AerosolKammer, LEAK). Oligomer formation was investigated as a function of seed particle acidity and relative humidity. A fraction of heat-decomposable methylglyoxal oligomers of up to $8 \%$ in the produced organic particle mass was found, highlighting the importance of those oligomers formed solely by methylglyoxal for SOA formation. Overall, the present study provides a new and suitable method for quantification of heatdecomposable methylglyoxal oligomers in the aqueous particle phase.
\end{abstract}

\section{Introduction}

Aromatic compounds represent a large fraction of the emitted hydrocarbons, contributing up to $52 \%$ to the total nonmethane hydrocarbon mass at an industrial dominated site in China (Liu et al., 2008). One of these aromatic compounds is 1,3,5-trimethylbenzene (TMB), which was measured in the gas phase in concentrations ranging from 0.7 to $40.6 \mu \mathrm{g} \mathrm{m}^{-3}$ (Gee and Sollars, 1998; Khoder, 2007). The gas-phase oxidation of 1,3,5-TMB leads to low-volatility oxidation products, which partition into the particle phase and form secondary organic aerosol (SOA). Oxidation products of 1,3,5TMB were investigated in a number of studies (e.g. Huang et al., 2015; Baltensperger et al., 2005; Kalberer et al., 2004, 2006; Paulsen et al., 2005; Healy et al., 2008; Cocker et al., 2001; Smith et al., 1999; Metzger et al., 2008; Wyche et al., 2009; Yu et al., 1997). Methylglyoxal was found as one of the most important oxidation product (Metzger et al., 2008; Healy et al., 2008; Cocker et al., 2001; Smith et al., 1999; Wyche et al., 2009; Baltensperger et al., 2005; Rickard et al., 2010; Kalberer et al., 2004; Yu et al., 1997; Kleindienst et al., 1999; Müller et al., 2012; Nishino et al., 2010; Hamilton et al., 2003; Tuazon et al., 1986; Bandow and Washida, 1985; Lim and Turpin, 2015) contributing with a fraction of up to $2 \%$ to the particle mass (Healy et al., 2008; Cocker et al., 2001). Methylglyoxal has often been described to form oligomeric compounds in the aqueous particle phase (see, e.g., Herrmann et al., 2015, for an overview; De Haan et al., 2009; Kalberer et al., 2004; Loeffler et al., 2006; Zhao et al., 2006; Sareen et al., 2010; Altieri et al., 2008), which are supposed to play an important role in the formation of aqueous secondary organic aerosols (aqSOA; e.g. Kalberer et al., 2004). 
Table 1. Overview of methods for structure elucidation of oligomeric compounds (after Hallquist et al., 2009).

\begin{tabular}{|c|c|}
\hline Method & Reference \\
\hline $\begin{array}{l}\text { (Matrix-assisted) laser desorption/ionisation mass } \\
\text { spectrometry (MALDI-MS, LDI-MS) }\end{array}$ & $\begin{array}{l}\text { Dommen et al. (2006); Kalberer et al. (2004, 2006); Reinhardt } \\
\text { et al. (2007); Holmes and Petrucci (2006); Surratt et al. (2006); } \\
\text { Denkenberger et al. (2007) }\end{array}$ \\
\hline $\begin{array}{l}\text { Fourier transform ion cyclotron resonance mass } \\
\text { spectrometry (FT-ICR-MS) }\end{array}$ & $\begin{array}{l}\text { Kundu et al. (2012); Altieri et al. (2008); Tolocka et al. (2004); } \\
\text { Hall and Johnston (2012); Denkenberger et al. (2007); Tan et al. } \\
\text { (2012) }\end{array}$ \\
\hline $\begin{array}{l}\text { Online atmospheric pressure chemical ionisation } \\
\text { tandem mass spectrometry } \\
\text { (APCI tandem MS) }\end{array}$ & Müller et al. (2008) \\
\hline Aerosol mass spectrometry (AMS) & $\begin{array}{l}\text { Sareen et al. (2010); Schwier et al. (2010); Bahreini et al. (2005); } \\
\text { Heaton et al. (2007) }\end{array}$ \\
\hline $\begin{array}{l}\text { Electrospray ionisation mass spectrometry } \\
\text { (ESI/MS, ESI/MS/MS) }\end{array}$ & $\begin{array}{l}\text { Altieri et al. (2008); Hall and Johnston (2012); Surratt et al. (2006, } \\
\text { 2007); Yasmeen et al. (2010); Hastings et al. (2005); Bones et al. } \\
\text { (2010); Hamilton et al. (2006); Sadezky et al. (2006); Sato et al. } \\
\text { (2012); Noziere et al. (2010); Tolocka et al. (2004); Iinuma et al. } \\
\text { (2004); Nguyen et al. (2011); Bahreini et al. (2005) }\end{array}$ \\
\hline $\begin{array}{l}\text { Aerosol time-of-flight mass spectrometry } \\
\text { (ALTOFMS) }\end{array}$ & Huang et al. (2015) \\
\hline Gas chromatography-mass spectrometry (GC/MS) & $\begin{array}{l}\text { Hastings et al. (2005); Surratt et al. (2006); Szmigielski et al. } \\
\text { (2007); Angove et al. (2006) }\end{array}$ \\
\hline Ion trap mass spectrometry (IT-MS) & Surratt et al. (2006); Gao et al. (2004) \\
\hline $\begin{array}{l}\text { Photoelectron resonance capture ionisation-aerosol } \\
\text { mass spectrometry (PERCI-MS) }\end{array}$ & Zahardis et al. (2005) \\
\hline Ultraviolet-visible spectroscopy (UV/Vis) & $\begin{array}{l}\text { Nemet et al. (2004); Noziere and Esteve (2005); Bones et al. (2010); } \\
\text { Song et al. (2013); Casale et al. (2007); Alfarra et al. (2006); Drozd } \\
\text { and McNeill (2014); Noziere and Cordova (2008) }\end{array}$ \\
\hline Fourier transform infrared spectroscopy (FTIR) & $\begin{array}{l}\text { Loeffler et al. (2006); Bones et al. (2010); Jang et al. (2003); Jang } \\
\text { and Kamens (2001); Holmes and Petrucci (2006) }\end{array}$ \\
\hline Nuclear magnetic resonance spectroscopy (NMR) & $\begin{array}{l}\text { Nemet et al. (2004); Bones et al. (2010); Angove et al. (2006); } \\
\text { Garland et al. (2006); Kua et al. (2013); De Haan et al. (2011) }\end{array}$ \\
\hline
\end{tabular}

In general, oligomeric compounds can be formed in the aqueous particle phase through aldol condensation (e.g. Tilgner and Herrmann, 2010; Sareen et al., 2010; Sedehi et al., 2013; Krizner et al., 2009; Barsanti and Pankow, 2005; De Haan et al., 2009; Yasmeen et al., 2010), acetal/hemiacetal formation (Kalberer et al., 2004; Yasmeen et al., 2010), esterification (Altieri et al., 2008; Sato et al., 2012; Tan et al., 2010; De Haan et al., 2011; Sedehi et al., 2013), imine formation (Altieri et al., 2008; Sato et al., 2012; Tan et al., 2010; De Haan et al., 2011; Sedehi et al., 2013), hydrolysis of epoxides (Paulot et al., 2009; Surratt et al., 2010), polymerisation, and radical-radical reactions (Schaefer et al., 2015; Tan et al., 2012; Lim et al., 2013).

During the last decade, huge efforts were undertaken to detect and identify oligomeric compounds. As can be seen in Table 1, a number of mass spectrometric meth- ods were used including (matrix-assisted) laser desorption/ionisation mass spectrometry (MALDI-MS, LDI-MS), Fourier transform ion cyclotron resonance mass spectrometry (FT-ICR-MS), electrospray ionisation mass spectrometry, and electrospray ionisation tandem mass spectrometry (ESI/MS, ESI/MS/MS). In addition, spectroscopic methods like UV/Vis (ultraviolet-visible spectroscopy), FTIR (Fourier transform infrared spectroscopy), and NMR (nuclear magnetic resonance spectroscopy) analysis were used for identification.

Despite the past effort for structure elucidation of oligomeric compounds a suitable quantification method is not available. Mostly, an overall contribution of oligomers to the particle mass was determined using, for example, a volatility tandem differential mobility analyser (VTDMA). Kalberer et al. (2004) determined an oligomer contribution 
of $50 \%$ to the particle mass formed by the photooxidation of 1,3,5-TMB. In a further experiment, oligomer mass fractions of 80 and $90 \%$ were determined with a VTDMAbased approach for 1,3,5-TMB and $\alpha$-pinene (Kalberer et al., 2006). Alfarra et al. (2006) investigated the photooxidation of 1,3,5-TMB and found an increase in the oligomer fraction of 3.1 and $3.7 \% \mathrm{~h}^{-1}$. A particulate oligomer fraction of $50 \%$ was reported for 1,3,5-TMB and $\alpha$-pinene by Baltensperger et al. (2005). Dommen et al. (2006) detected a contribution of oligomers to the organic particle mass increasing from 27 to $44 \%$ in the first $5 \mathrm{~h}$ of the photooxidation of isoprene. Nguyen et al. (2011) investigated oligomers from isoprene photooxidation with ESI-MS and nano-DESI-MS (nanospray desorption electrospray ionisation) connected to a high-resolution linear ion trap (LTQ) orbitrap. They calculated an oligomer fraction of 80-90\%.

De Haan et al. (2009) estimated the oligomer fraction formed by methylglyoxal in the aqueous phase with NMR concluding $37 \%$ of methylglyoxal are dimers and oligomers. In another approach it was estimated that after 4 days in aqueous particles containing amino acids, $15 \%$ of the carbonyl compounds are oligomers (Noziere et al., 2007). In contrast, with ammonium sulfate particles $30 \%$ of the carbonyl compounds are converted into oligomers (Noziere et al., 2007). These estimations are based on the rate constants for oligomer formation which were determined in the study by Noziere et al. (2007). Besides these estimations, quantification of oligomeric compounds was also conducted using surrogate compounds (Surratt et al., 2006; Zappoli et al., 1999; Gao et al., 2004) or synthesised authentic standards (Birdsall et al., 2013).

In summary, a variety of methods exists which quantify the fraction of oligomeric compounds derived from methylglyoxal, but the results are contradictory due to the lack of a suitable method for quantification and second, due to different reaction conditions used in the studies. Thus, the present study presents a fundamental approach for a reliable quantification of methylglyoxal oligomers in laboratorygenerated SOA. The method is applicable for any oligomeric compounds, which can be decomposed into methylglyoxal monomers during the heating process at a temperature of $100^{\circ} \mathrm{C}$. As the oligomerisation mechanisms leading to the quantified oligomeric compounds are not known, it cannot be specified whether the oligomers are reversibly or irreversibly formed. In addition, it cannot be excluded that oligomers exist which are not decomposable into their methylglyoxal monomers through the heating process. Thus, the quantified oligomers are termed as heat-decomposable methylglyoxal oligomers.

\section{Experimental}

\subsection{Chemicals and standards}

1,3,5-TMB ( $\geq 99.8 \%)$, hydrochloric acid (37\%), tetramethylethylene (99\%), and sodium hydroxide (50-52\%) were obtained from Sigma-Aldrich (Hamburg, Germany). $O$ (2,3,4,5,6-Pentafluorobenzyl)-hydroxylamine hydrochloride ( $\geq 99 \%$ ), methylglyoxal (40\% in water), and ammonium hydrogen sulfate $(98 \%)$ were purchased from Fluka (Hamburg, Germany). Sulfuric acid (98\%) was obtained from Merck KGaA (Darmstadt, Germany). Dichloromethane (Chromasolv $99.8 \%$ ) was obtained from Riedel-de Haen (Seelze, Germany) and ammonium sulfate (99.5\%) was purchased from Carl Roth (Karlsruhe, Germany). Ultrapure water was used to prepare the seed particle solutions and authentic standards and to extract the filter samples (Milli-Q gradient A 10, $18.2 \mathrm{M} \Omega \mathrm{cm}, 3 \mathrm{ppb}$ TOC, Millipore, USA).

\subsection{Chamber experiments}

The OH-radical oxidation of 1,3,5-TMB was investigated in the LEipziger AerosolKammer (LEAK). A detailed description of the aerosol chamber can be found elsewhere (Mutzel et al., 2016). The conditions of the experimental runs are summarised in Table 2. The experiments were conducted in the presence of ammonium bisulfate particles or ammonium sulfate particles mixed with sulfuric acid to achieve different seed acidities. In order to investigate $\mathrm{OH}$-radical oxidation of 1,3,5-TMB at low $\mathrm{NO}_{x}$ levels $(<1 \mathrm{ppb})$ and under dark conditions the ozonolysis of tetramethylethylene (TME) was used as OH-radical source (Berndt and Böge, 2006). The cycloaddition of ozone to TME yields a primary ozonide, which reacts further and forms a stabilised Criegee intermediate (sCI). The sCI decomposes via the hydroperoxide channel, leading to the formation of $\mathrm{OH}$ radicals (Gutbrod et al., 1996) with a yield of $0.92 \pm 0.08$ (Berndt and Böge, 2006). $\mathrm{O}_{3}$ was produced by $\mathrm{UV}$ irradiation of $\mathrm{O}_{2}$ with an $\mathrm{O}_{2}$ flow rate of $5 \mathrm{~L} \mathrm{~min}^{-1}$. It was injected at the beginning of the experiments and $\approx 26 \mathrm{ppbv}$ of TME was introduced into the aerosol chamber in steps of $15 \mathrm{~min} .1,3,5-\mathrm{TMB}(\approx 92 \mathrm{ppb})$ was injected into the aerosol chamber using a microlitre syringe. The oxidation of 1,3,5-TMB was studied at relative humidities $(\mathrm{RH})$ between $\approx 0$ and $75 \%$ adjusted by flushing the aerosol chamber with humid or dry air. The consumption of the precursor compound $(\Delta \mathrm{HC})$ was monitored over a reaction time of $90 \mathrm{~min}$ with a proton-transfer-reaction time-of-flight mass spectrometer (PTR-TOF MS; 8000, IONICON Analytik, Innsbruck, Germany). The volume size distribution of the seed particles was measured with a scanning mobility particle sizer (SMPS; 3010; TSI, USA). An average density of $1 \mathrm{~g} \mathrm{~cm}^{-3}$ was used to calculate the increase in the organic particle mass $(\Delta \mathrm{M})$. To collect the particle phase after the experiments, $1.2 \mathrm{~m}^{3}$ of the chamber volume was sampled on a PTFE filter (borosilicate glass fibre filter 
Table 2. Experiments in the aerosol chamber LEAK for the $\mathrm{OH}$ radical oxidation of 1,3,5-TMB. All experiments were conducted at $293 \mathrm{~K}$ and with $91.9 \mathrm{ppb} 1,3,5-\mathrm{TMB}$.

\begin{tabular}{llrrrrc}
\hline $\begin{array}{l}\text { Experiment } \\
\text { number }\end{array}$ & Seed & $\begin{array}{r}\mathrm{RH} \\
(\%)\end{array}$ & $\begin{array}{c}\mathrm{O}_{3 \mathrm{ini}} \\
(\mathrm{ppb})\end{array}$ & $\begin{array}{c}\Delta \mathrm{HC} \\
(\mathrm{ppb})\end{array}$ & $\begin{array}{c}\Delta \mathrm{M} \\
\left(\mu \mathrm{g} \mathrm{m}^{-3}\right)\end{array}$ & $\begin{array}{c}\text { SOA yield } \\
Y_{\mathrm{SOA}}(\%)\end{array}$ \\
\hline$\# 1$ & $78 \mathrm{mmol} \mathrm{L}^{-1} \mathrm{NH}_{4} \mathrm{HSO}_{4}$ & $\approx 0$ & $\approx 137$ & 57.2 & 19.7 & 7.00 \\
$\# 2$ & $78 \mathrm{mmol} \mathrm{L}^{-1} \mathrm{NH}_{4} \mathrm{HSO}_{4}$ & 50 & $\approx 133$ & 55.2 & 11.3 & 4.12 \\
$\# 3$ & $78 \mathrm{mmol} \mathrm{L}^{-1} \mathrm{NH}_{4} \mathrm{HSO}_{4}$ & 75 & $\approx 134$ & 56.2 & 14.2 & 5.14 \\
$\# 4$ & $60 \mathrm{mmol} \mathrm{L}^{-1}\left(\mathrm{NH}_{4}\right)_{2} \mathrm{SO}_{4} /$ & $\approx 0$ & $\approx 132$ & 56.2 & 18.1 & 6.55 \\
$\# 5$ & $0.4 \mathrm{mmol} \mathrm{L}^{-1} \mathrm{H}_{2} \mathrm{SO}_{4}$ & & & & & 4.21 \\
& $60 \mathrm{mmol} \mathrm{L}^{-1}\left(\mathrm{NH}_{4}\right)_{2} \mathrm{SO}_{4} /$ & 50 & $\approx 135$ & 56.5 & 11.7 & 4.21 \\
$\# 6$ & $0.4 \mathrm{mmol} \mathrm{L}^{-1} \mathrm{H}_{2} \mathrm{SO}_{4}$ & & & & & 4 \\
& $60 \mathrm{mmol} \mathrm{L}^{-1}\left(\mathrm{NH}_{4}\right)_{2} \mathrm{SO}_{4} /$ & 75 & $\approx 144$ & 57.2 & 13.9 & 4.94 \\
\hline
\end{tabular}

1,3,5-TMB: 1,3,5-trimethylbenzene; RH: relative humidity.

coated with fluorocarbon, $47 \mathrm{~mm}$ in diameter, PALLFLEX T60A20, PALL, NY, USA) connected to a XAD-4-coated denuder (URG-2000-30B5, URG Corporation, Chapel Hill, NC, USA; Kahnt et al., 2011) to avoid artefacts caused by adsorption of gas-phase organic compounds onto the filter.

\subsection{Sample preparation}

For method development, PTFE filter samples from aerosol chamber experiments were used. The following method parameters were investigated: heating time, $\mathrm{pH}$ during the heating process, and heating temperature (Table 3 ). Filter samples from the same experiments were used for the optimisation of the respective method parameters.

\subsubsection{Filter extraction}

Two halves of the PTFE filters were cut into small pieces. Each filter half was extracted separately with $1 \mathrm{~mL}$ of $\mathrm{H}_{2} \mathrm{O}$ for $30 \mathrm{~min}$ using an orbital shaker $(700 \mathrm{rpm}$, revolutions per minutes). They were shaken again separately with $1 \mathrm{~mL}$ of $\mathrm{H}_{2} \mathrm{O}$ for $30 \mathrm{~min}$ and flushed at the end of the procedure with $1 \mathrm{~mL}$ of $\mathrm{H}_{2} \mathrm{O}$, resulting in two $3 \mathrm{~mL}$ extracts. Notably, the extraction efficiency was not investigated in the present study and is thus not known. Water was used as extracting reagent because organic solvents like methanol and acetonitrile have lower boiling points than water, and thus lower heating temperatures can be applied for the decomposition of the oligomers. Besides this, organic solvents like methanol and acetonitrile are miscible with dichloromethane, and thus an extraction of the derivatised methylglyoxal with dichloromethane prior the injection into GC/MS would not be possible. The extract of one half of the filter was used for oligomer measurements (extract 1) and with the second one methylglyoxal monomers were quantified which were not a building block of oligomers (extract 2). A detailed description of the derivatisation procedure can be found in Rodigast et al. (2015).
Table 3. Investigated method parameters and used PTFE filters from 1,3,5-TMB oxidation for method development.

\begin{tabular}{llc}
\hline Parameter & Range & $\begin{array}{c}\text { Filter of } \\
\text { experiment }\end{array}$ \\
\hline Heating time & $15, \mathbf{2 4}, 30,48 \mathrm{~h}$ & $\# 3$ \\
$\mathrm{pH}$ & $\mathbf{1 , 3 , 5 , 7}$ & $\# 2$ \\
Heating temperature & $50, \mathbf{1 0 0}^{\circ} \mathrm{C}$ & $\# 2$ \\
\hline
\end{tabular}

Selected parameters given in bold.

\subsubsection{Derivatisation procedure}

\section{Extract 1 - heat-decomposable methylglyoxal oligomers}

For quantification of heat-decomposable methylglyoxal oligomers the extract was acidified and heated to decompose the oligomeric bonds. The $\mathrm{pH}$ was adjusted with hydrochloric acid $(37 \%)$ or sodium hydroxide $\left(1 \mathrm{~mol} \mathrm{~L}^{-1}\right)$ to $\mathrm{pH}=1,3,5$, and 7 while heating temperatures of 50 and $100^{\circ} \mathrm{C}$ were investigated. For the derivatisation of the formed monomeric methylglyoxal, $300 \mu \mathrm{L}$ of $o-(2,3,4,5,6-$ pentafluorobenzyl)hydroxylamine hydrochloride (PFBHA, $5 \mathrm{mg} \mathrm{mL}^{-1}$ ) was added to the sample solution after $2 \mathrm{~min}$ of the heating process. Different heating times were tested varying between 15 and $48 \mathrm{~h}$. After the derivatisation was complete, the extracts were allowed to cool down to room temperature.

\section{Extract 2 - methylglyoxal monomer}

The second half of the filters was used to quantify monomeric methylglyoxal including also singly and doubly hydrated methylglyoxal, which can be hydrolysed at room temperature into monomers. The filters were prepared according to the method described by Rodigast et al. (2015); thus, $300 \mu \mathrm{L}$ of an aqueous PFBHA solution $\left(5 \mathrm{mg} \mathrm{mL}^{-1}\right)$ was added to 

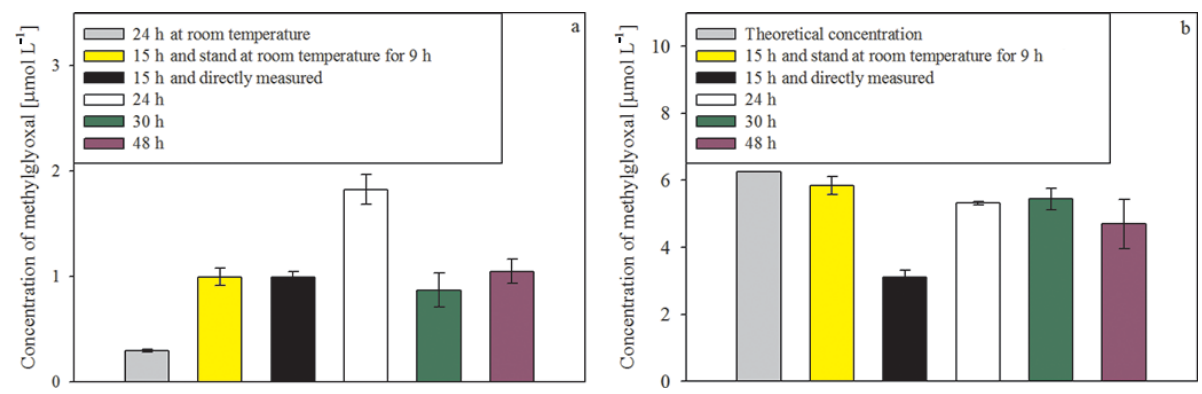

Figure 1. Influence of the heating time on the detected methylglyoxal concentrations in filter samples (a) and the methylglyoxal standard solution (b).

the filter extracts. After a derivatisation time of $24 \mathrm{~h}$ at room temperature the derivatised methylglyoxal monomers were extracted.

\subsubsection{Extraction for GC/MS analysis}

After derivatisation of both filter extracts (extract 1 and 2), derivatised methylglyoxal was extracted at $\mathrm{pH}=1$ for $30 \mathrm{~min}$ with $250 \mu \mathrm{L}$ of dichloromethane using an orbital shaker (1500 rpm; Rodigast et al., 2015). One microlitre of the organic phase was injected into GC/MS for analysis. The measurements were repeated three times to ensure reliable GC/MS signals.

For quantification, a five-point calibration was performed at the beginning of each chromatographic run using a standard solution of methylglyoxal in a concentration range of 0.13 to $8 \mu \mathrm{mol} \mathrm{L}^{-1}$.

\subsection{Instrumentation}

The samples were analysed using a GC system (6890 Series Agilent Technologies, Frankfurt, Germany) coupled with an electron ionisation quadrupole mass spectrometer in splitless mode with an inlet temperature of $250^{\circ} \mathrm{C}$ (Agilent 5973Network mass selective detector, Frankfurt, Germany). The derivatives were separated with a HP-5MS UI column (Agilent J \& W GC columns, $30 \mathrm{~m} \times 0.25 \mathrm{~mm} \times 0.25 \mu \mathrm{m}$ ) using the following temperature programme: $50^{\circ} \mathrm{C}$ isothermal for $2 \mathrm{~min}$ and elevated to $230^{\circ} \mathrm{C}\left(10^{\circ} \mathrm{C} \mathrm{min}{ }^{-1}\right)$. The temperature of $230^{\circ} \mathrm{C}$ was held constant for $1 \mathrm{~min}$ and ended with $320^{\circ} \mathrm{C}$ for $10 \mathrm{~min}$; thus, the method has a run time of $36 \mathrm{~min}$.

\section{Results}

Hastings et al. (2005) investigated the influence of the temperature of the GC inlet on the detection of oligomeric compounds. These authors concluded that oligomers decompose into monomer building blocks at higher inlet temperatures $\left(\geq 120^{\circ} \mathrm{C}\right.$ ), which caused problems for oligomer quantification. In the present study a quantification method is proposed to decompose heat-decomposable oligomers into methylgly- oxal monomers due to heating, acidification and PFBHA derivatisation prior GC/MS injection.

$(E)$ and $(Z)$ isomers of methylglyoxal were formed during PFBHA derivatisation resulting in two peaks in the GC/MS chromatogram. For quantification, the sum of these peaks was used to avoid an over- or underestimation of methylglyoxal due to variations in the isomer peak ratio during the heating process.

\subsection{Method development}

\subsubsection{Influence of heating time}

The influence of the heating time was examined with PTFE filters which were sampled after $\mathrm{OH}$-radical oxidation of $1,3,5-\mathrm{TMB}$ at $\mathrm{RH}=75 \%$ in the presence of $\mathrm{NH}_{4} \mathrm{HSO}_{4}$ seed particles (experiment \#3). To investigate the effect of the heating time on the decomposition of the heatdecomposable oligomeric compounds, the aqueous filter extracts (extract 1) were acidified to $\mathrm{pH}=1$ and heated to $100^{\circ} \mathrm{C}$ for $15-48 \mathrm{~h}$. The results were compared to the unheated aqueous filter extracts (extract 2) to determine the increase in methylglyoxal concentration due to decomposition of the heat-decomposable oligomers. Additionally, a $6.25 \mu \mathrm{mol} \mathrm{L}^{-1}$ standard solution of methylglyoxal was acidified and heated for different times to exclude an effect of the heating process on the derivatisation. The results are illustrated in Fig. 1a.

The highest methylglyoxal concentration can be found after a heating time of $24 \mathrm{~h}$. The methylglyoxal concentration was about 6 times higher $\left(c=1.82 \pm 0.14 \mu \mathrm{mol} \mathrm{L}^{-1}\right)$ in comparison to the unheated filter extract $\left(c=0.29 \pm 0.01 \mu \mathrm{mol} \mathrm{L}^{-1}\right)$. To exclude that the higher methylglyoxal concentrations were only a result of a better PFBHA derivatisation during heating, a methylglyoxal standard solution was also heated for $24 \mathrm{~h}$ (Fig. 1b). A methylglyoxal concentration of $c=5.32 \pm 0.05 \mu \mathrm{mol} \mathrm{L}{ }^{-1}$ was found, which corresponds to a recovery of $\approx 85 \%$. Thus, an effect of the heating process on the derivatisation can be excluded indicating that the higher 

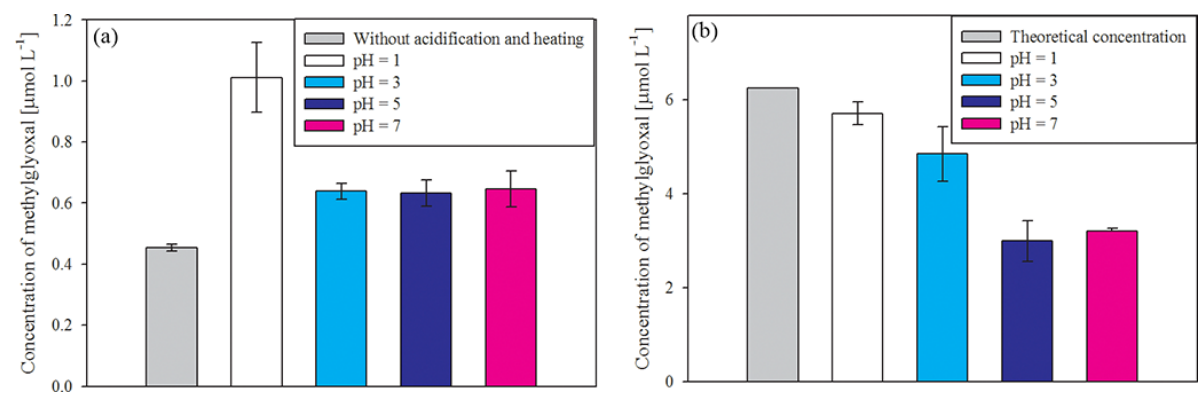

Figure 2. Influence of $\mathrm{pH}$ on the detected methylglyoxal concentration in filter samples (a) and the methylglyoxal standard solution (b).

methylglyoxal concentration was caused by decomposition of heat-decomposable oligomers into monomers.

One filter extract was heated for $15 \mathrm{~h}$ and allowed to stand at room temperature for $9 \mathrm{~h}$ (sample A) to reach a total derivatisation time of $24 \mathrm{~h}$ (as it was optimised for PFBHA derivatisation by Rodigast et al., 2015). To exclude reoligomerisation processes of methylglyoxal in sample A, one filter extract was heated for $15 \mathrm{~h}$ and measured directly after the heating process (sample B). As can be seen in Fig. 1a, both filter samples (sample A and B) showed lower methylglyoxal concentrations than after heating for $24 \mathrm{~h}$. The lower methylglyoxal concentration of sample B might be caused by an incomplete derivatisation due to the immediate measurement of the filter extract after $15 \mathrm{~h}$ heating time. In comparison, the lower concentration in sample A might be caused by reoligomerisation of methylglyoxal.

To probe this hypothesis a $6.25 \mu \mathrm{molL} \mathrm{L}^{-1}$ methylglyoxal standard was heated for $15 \mathrm{~h}$ and measured immediately (like sample A) or, alternatively, was allowed to stand at room temperature for $9 \mathrm{~h}$ (like sample B). In Fig. $1 \mathrm{~b}$ a lower methylglyoxal concentration can be observed for the immediately measured sample $\left(3.11 \pm 0.20 \mu \mathrm{mol} \mathrm{L}^{-1}\right)$ compared to the sample after $9 \mathrm{~h}$ at room temperature $\left(5.84 \pm 0.27 \mu \mathrm{mol} \mathrm{L}^{-1}\right)$. Thus, it can be concluded that a derivatisation time of $24 \mathrm{~h}$ is needed for a complete derivatisation despite the heating process. This supports the hypothesis that methylglyoxal monomers were not completely derivatised if the filter sample was heated for $15 \mathrm{~h}$ and directly measured (sample B). Based on the incomplete derivatisation after $15 \mathrm{~h}$ heating time, methylglyoxal monomers are able to react again under oligomer formation during the $9 \mathrm{~h}$ at room temperature. The rate constants are reported to be $k=5 \times 10^{-6} \mathrm{M}^{-1} \mathrm{~min}^{-1}$ for ammonium ioncatalysed reaction and $k \leq 1 \times 10^{-3} \mathrm{M}^{-1} \mathrm{~min}^{-1}$ for $\mathrm{H}_{3} \mathrm{O}^{+}$. catalysed aldol reaction (Sareen et al., 2010). Naturally, both of these ions are present in the aqueous filter extract. Despite the oligomerisation of methylglyoxal monomers during the $9 \mathrm{~h}$ at room temperature, the derivatisation proceeds as well during this time, leading to higher methylglyoxal concentrations in sample B than in sample A, which was directly measured after $15 \mathrm{~h}$ heating (Fig. 1a).
Longer heating times than $24 \mathrm{~h}$ ( 30 and $48 \mathrm{~h}$ ) led to lower methylglyoxal concentrations in the filter samples as well. A possible explanation might be the decomposition of the derivatised compound during the long heating process. As no decrease in the concentration was observed in the methylglyoxal standard solution (Fig. 1b), the loss of the derivatisation group is unlikely as a reason for the lower concentrations. Thus, it can be speculated that the low methylglyoxal concentrations in the filter samples are a result of further reactions with particle-phase species, which do not exist in the standard samples. Based on the outlined results, a heating time of $24 \mathrm{~h}$ was chosen.

The $\mathrm{pH}$ during the heating process was investigated as well.

\subsubsection{Influence of $\mathbf{p H}$}

The effect of the $\mathrm{pH}$ was examined with PTFE filters, which were sampled after $\mathrm{OH}$-radical oxidation of 1,3,5-TMB at $\mathrm{RH}=50 \%$ in the presence of $\mathrm{NH}_{4} \mathrm{HSO}_{4}$ particles (experiment \#2). The $\mathrm{pH}$ was varied between $\mathrm{pH}=1$ and $\mathrm{pH}=7$.

As can be seen in Fig. 2a the highest methylglyoxal concentration can be found at $\mathrm{pH}=1$. The methylglyoxal concentration was about 2 times higher at $\mathrm{pH}=1 \quad\left(c=1.01 \pm 0.11 \mu \mathrm{mol} \mathrm{L}^{-1}\right) \quad$ compared to the filter extract, which was neither heated nor acidified $\left(c=0.45 \pm 0.01 \mu \mathrm{mol} \mathrm{L}^{-1}\right)$. An increasing $\mathrm{pH}$ leads to a lower methylglyoxal concentration, which can be observed for filter samples (Fig. 2a) as well as for the methylglyoxal standard solution (Fig. 2b). As this was observed for both types of samples, it appears that the $\mathrm{pH}$ influences the derivatisation and/or the oligomer decomposition. No influence of the $\mathrm{pH}$ on the PFBHA derivatisation reaction was reported by Rodigast et al. (2015), indicating the effect of the $\mathrm{pH}$ is connected to thermal decomposition of the heatdecomposable oligomeric compounds. In summary, based on these results, $\mathrm{pH}=1$ was used.

\subsubsection{Influence of heating temperature}

The effect of the heating temperature was examined with filter samples of experiment $\# 2$. The heating temperature was 

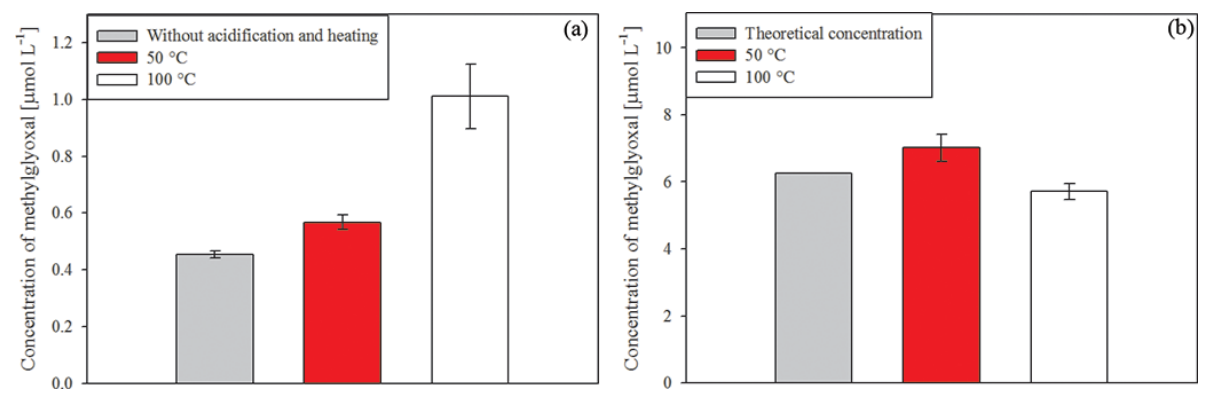

Figure 3. Influence of the heating temperature on the detected methylglyoxal concentration in filter samples (a) and the standard solution (b).

varied between 50 and $100^{\circ} \mathrm{C}$ and the filter extracts were heated for $24 \mathrm{~h}$ at $\mathrm{pH}=1$. A temperature above $100^{\circ} \mathrm{C}$ cannot be used to avoid evaporation of water and/or target compounds. Figure 3a shows the influence of the temperature on the decomposition of the heat-decomposable methylglyoxal oligomers into monomers. Higher concentration of methylglyoxal can be detected with higher temperature. The results illustrated in Fig. 3a indicate that a higher temperature than $50^{\circ} \mathrm{C}$ is needed to decompose the oligomeric compounds. In comparison to the filter, which was neither acidified nor heated, the concentration increased by a factor of 2 if the extract was heated to $100^{\circ} \mathrm{C}$. Figure $3 \mathrm{~b}$ shows no significant influence of the temperature on the methylglyoxal standard solution. Thus, an influence of the heating temperature on the derivatisation procedure can be excluded.

Based on these results, the PTFE filter extracts from the aerosol chamber experiments were acidified to $\mathrm{pH}=1$ and heated for $24 \mathrm{~h}$ to $100^{\circ} \mathrm{C}$ to decompose heat-decomposable oligomeric compounds into methylglyoxal. According to the literature, other carbonyl compounds can be expected as particle-phase products, e.g. propionaldehyde (Cocker et al., 2001), glyoxal (Cocker et al., 2001; Huang et al., 2015), 2-methyl-4-oxo-2-pentenal (Healy et al., 2008; Huang et al., 2014), glycolaldehyde (Cocker et al., 2001) and 3,5dimethylbenzaldehyde (Huang et al., 2014). Noticeably, no carbonyl compounds other than methylglyoxal were identified, which showed an increase after thermal decomposition.

The developed quantification method was afterwards applied to laboratory-generated SOA formed during further oxidation experiments of 1,3,5-TMB to investigate the influence of seed particle acidity and relative humidity on the oligomer content.

\subsection{SOA yield and growth curves of 1,3,5-TMB oxidation}

SOA formation of 1,3,5-TMB was investigated in a number of studies mostly in the presence of $\mathrm{NO}_{x}$ and under variation in the hydrocarbon to $\mathrm{NO}_{x}$ ratio $\left([\mathrm{HC}] /\left[\mathrm{NO}_{x}\right]\right.$ ratio). Healy et al. (2008) determined SOA yields ( $\left.Y_{\mathrm{SOA}}\right)$ of 1,3,5-TMB photooxidation ranging from 4.5 to $8.3 \%$. Further studies determined $Y_{\text {SOA }}$ between 0.29 and $15.6 \%$ (Table 4) under vari-
Table 4. SOA yields $\left(Y_{\mathrm{SOA}}\right)$ of 1,3,5-TMB reported in the literature.

\begin{tabular}{ll}
\hline SOA yield $Y_{\text {SOA }}(\%)$ & Reference \\
\hline $2.81-7.91$ & Cocker et al. (2001) \\
$4.5-8.34$ & Healy et al. (2008) \\
$2.5 \pm 0.1-15.6 \pm 1.0$ & Sato et al. (2012) \\
3.1 & Odum et al. (1997) \\
$0.41 \pm 0.1$ & Kleindienst et al. (1999) \\
$0.29-6.36$ & Wyche et al. (2009) \\
$4.7 \pm 0.7$ & Paulsen et al. (2005) \\
$7.1 \pm 0.3-13.8 \pm 0.6$ & Cao and Jang (2007) \\
$4.12-7.00$ & This work \\
\hline
\end{tabular}

ation in the $[\mathrm{HC}] /\left[\mathrm{NO}_{x}\right]$ ratio, concluding that SOA formation is enhanced at low $\mathrm{NO}_{x}$ mixing ratios (Sato et al., 2012; Kleindienst et al., 1999; Baltensperger et al., 2005; Wyche et al., 2009; Odum et al., 1997; Paulsen et al., 2005; Cocker et al., 2001). Only Cao and Jang (2007) investigated SOA yields in the absence of $\mathrm{NO}_{x}$ and reported values between 7.1 and $13.8 \%$. The SOA yields were also determined in the present study for all conducted experiments based on the ratio of $\Delta \mathrm{M}$ to $\triangle \mathrm{HC}$ (Table 2). Notably, the SOA yields of $1,3,5$-TMB are not corrected for the wall loss to the surface of the aerosol chamber, which might possibly lead to an underestimation of the reported SOA yields. $Y_{\text {SOA }}$ varied between 4 and $7 \%$ dependent on reaction conditions and is in good agreement with literature values.

For a further investigation of SOA-formation processes of 1,3,5-TMB, Fig. 4a illustrates the dependency between the consumption of $1,3,5-\mathrm{TMB}(\triangle \mathrm{HC})$ and the produced organic particle mass $(\Delta \mathrm{M})$. Particle growth started directly after the experiment was initialised indicating that the oxidation leads immediately to the formation of condensable products as first-generation oxidation products. These products condense on the pre-existing seed particles resulting in the immediate particle growth observed in Fig. 4a. Differences of the growth curves depending on the seed particles $\left(\mathrm{NH}_{4} \mathrm{HSO}_{4}\right.$ and $\left.\left(\mathrm{NH}_{4}\right)_{2} \mathrm{SO}_{4} / \mathrm{H}_{2} \mathrm{SO}_{4}\right)$ were not observed, leading to the conclusion that the seed particle acidity (Table 5) has no influence on the SOA formation of 1,3,5-TMB. 
Table 5. LWC and $\mathrm{pH}$ of the seed particles calculated with E-AIM.

\begin{tabular}{lrll}
\hline Seed & $\begin{array}{r}\mathrm{RH} \\
(\%)\end{array}$ & $\begin{array}{l}\mathrm{pH}_{\text {seed }}^{\mathrm{a}} \\
\end{array}$ & $\begin{array}{l}\mathrm{LWC} \\
\left(\mathrm{g} \mathrm{m}^{-3}\right)^{\mathrm{a}}\end{array}$ \\
\hline $78 \mathrm{mmol} \mathrm{L}^{-1} \mathrm{NH}_{4} \mathrm{HSO}_{4}$ & 0 & $-\mathrm{b}$ & $-^{\mathrm{b}}$ \\
$78 \mathrm{mmol} \mathrm{L}^{-1} \mathrm{NH}_{4} \mathrm{HSO}_{4}$ & 50 & 0.1 & $6.66 \times 10^{-6}$ \\
$78 \mathrm{mmol} \mathrm{L}^{-1} \mathrm{NH}_{4} \mathrm{HSO}_{4}$ & 75 & 1.2 & $12.29 \times 10^{-6}$ \\
$60 \mathrm{mmol} \mathrm{L}^{-1}\left(\mathrm{NH}_{4}\right)_{2} \mathrm{SO}_{4} / 0.4 \mathrm{mmol} \mathrm{L}^{-1} \mathrm{H}_{2} \mathrm{SO}_{4}$ & $\approx 0$ & $-{ }^{\mathrm{b}}$ & $-{ }^{\mathrm{b}}$ \\
$60 \mathrm{mmol} \mathrm{L}^{-1}\left(\mathrm{NH}_{4}\right)_{2} \mathrm{SO}_{4} / 0.4 \mathrm{mmol} \mathrm{L}^{-1} \mathrm{H}_{2} \mathrm{SO}_{4}$ & 50 & 4.0 & $4.25 \times 10^{-6}$ \\
$60 \mathrm{mmol} \mathrm{L}^{-1}\left(\mathrm{NH}_{4}\right)_{2} \mathrm{SO}_{4} / 0.4 \mathrm{mmol} \mathrm{L}^{-1} \mathrm{H}_{2} \mathrm{SO}_{4}$ & 75 & 4.2 & $11.56 \times 10^{-6}$ \\
\hline
\end{tabular}

LWC: liquid water content; ${ }^{\mathrm{a}} \mathrm{pH}$ and LWC of the seed particles were calculated for different $\mathrm{RH}$ using model II from the extended aerosol thermodynamic model (E-AIM; Clegg et al., 1998); ${ }^{\mathrm{b}}$ calculation of the $\mathrm{pH}$ and LWC was not possible due to the low relative humidity of $\mathrm{RH} \approx 0 \%$. A RH $=10 \%$ is set as the lower limit in E-AIM.
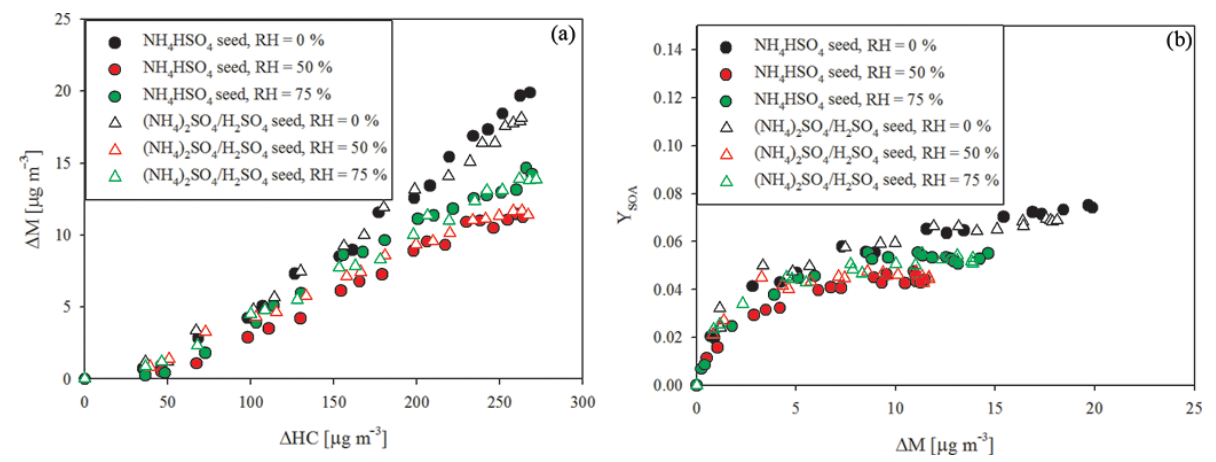

Figure 4. SOA growth curve (a) and yield curve (b) of the $\mathrm{OH}$ radical oxidation of $1,3,5-\mathrm{TMB}$ in the presence of $\mathrm{NH}_{4} \mathrm{HSO}_{4}$ or $\left(\mathrm{NH}_{4}\right)_{2} \mathrm{SO}_{4} / \mathrm{H}_{2} \mathrm{SO}_{4}$ seed under variation in $\mathrm{RH}$.

Cao and Jang (2007) also found only a small influence of seed particle acidity on SOA formation.

Figure 4a showed great differences in the growth curves under variation in RH. The RH value can have an influence on the phase state of the particles which, in turn, has an effect on the partitioning of the compounds into the particles as well as on particle-phase reactions (Ziemann, 2010; Saukko et al., 2012). The deliquescence $\mathrm{RH}$ of $\left(\mathrm{NH}_{4}\right)_{2} \mathrm{SO}_{4}$ and $\mathrm{NH}_{4} \mathrm{HSO}_{4}$ seed particles are known from literature to be 79 and $39 \%$, respectively (Cziczo et al., 1997). Thus, pure $\mathrm{NH}_{4} \mathrm{HSO}_{4}$ seed particles are liquid at the applied $\mathrm{RH}$ values of 50 and $75 \%$ and solid at $\mathrm{RH}=0 \%$, while $\left(\mathrm{NH}_{4}\right)_{2} \mathrm{SO}_{4}$ seed particles are solid over the whole RH range. Nevertheless, in the present study the particles are a mixture of inorganic and partitioned organic compounds. Organic compounds might change the phase state of the particles (Bertram et al., 2011) due to an influence on the deliquescence point (Andrews and Larson, 1993; Lightstone et al., 2000) as well as the hygroscopic behaviour of the particles (Lightstone et al., 2000; Prenni et al., 2003; Chen and Lee, 1999). Virtanen et al. (2010) postulated that particles are in an amorphous solid state if oligomeric compounds are present in the particles. Thus, it can be speculated that the particles in the present study containing a fraction of up to $8 \%$ of oligomeric compounds might be in an amorphous solid-phase state. It was assumed that the further reactions in the particle phase might be inhibited in solid particles (Saukko et al., 2012); thus, further oligomerisation or other reactions might become less effective after a certain fraction of oligomers exist in the particles. In addition, the partitioning of methylglyoxal monomers can be inhibited into solid particles (Saukko et al., 2012), which then might also lead to lower oligomer fractions in SOA. Thus, it might be possible that the phase state influences $\Delta \mathrm{M}$ and the SOA yields. $\Delta \mathrm{M}$ is the highest at $\mathrm{RH}=0 \%$ $\left(\Delta \mathrm{M}=18.1-19.7 \mu \mathrm{g} \mathrm{m}^{-3}\right)$, whereas $\Delta \mathrm{M}$ is the lowest under humid conditions $(\mathrm{RH}=50$ and $75 \%, \Delta \mathrm{M}=11.3-11.7$ and $13.9-14.2 \mu \mathrm{g} \mathrm{m}^{-3}$ ). Due to the variation in RH in the aerosol chamber the liquid water content (LWC) of the particles is changing (Table 5). The LWC was calculated using model II from the extended aerosol thermodynamic model (E-AIM; Clegg et al., 1998). With increasing RH the LWC of the seed particle increases as well. The LWC of the seed particles influences (i) the partitioning of the compounds from the gas phase into the particle phase and (ii) the formation and/or further reaction in the particle phase (Zuend et al., 2010; Cocker et al., 2001; Seinfeld et al., 2001; Fick et al., 2003). These two effects might influence the SOA formation under different relative humidities.

An effect can also be seen in Fig. 4b. The SOA formation is enhanced at $\mathrm{RH}=0 \%$ leading to the highest SOA yields 

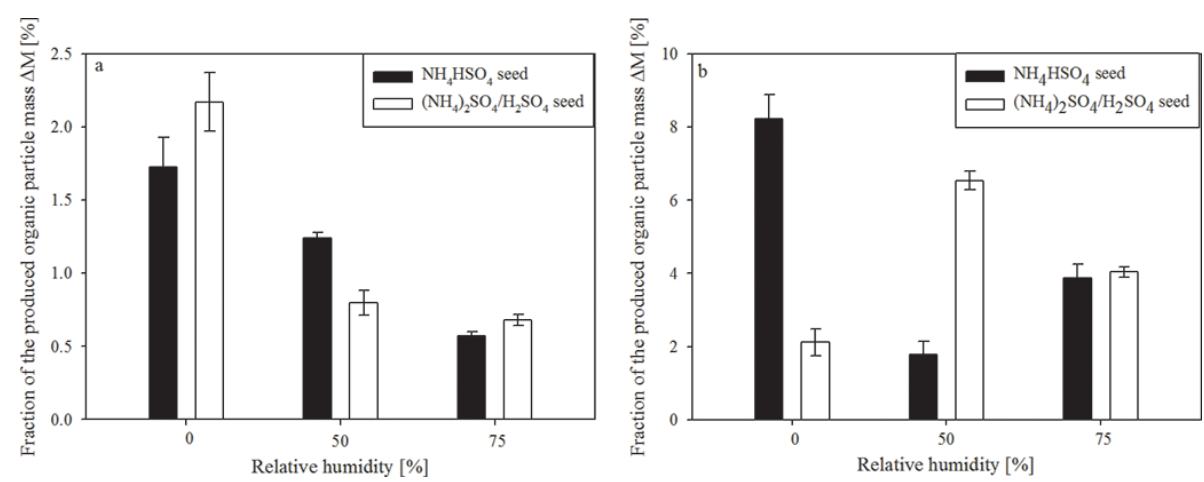

Figure 5. Contribution of methylglyoxal (a) and their heat-decomposable oligomers (b) to the produced organic particle mass $(\Delta \mathrm{M})$ with $\mathrm{NH}_{4} \mathrm{HSO}_{4}$ and $\left(\mathrm{NH}_{4}\right)_{2} \mathrm{SO}_{4} / \mathrm{H}_{2} \mathrm{SO}_{4}$ seed particles under variation in the relative humidity.

of $Y_{\mathrm{SOA}} \approx 7 \%$ for both seed particles. Higher RH values resulted in lower $Y_{\mathrm{SOA}}$ between 4 and $5 \%$. These findings are in good agreement with the study by Cao and Jang (2007), which observed lower $Y_{\text {SOA }}$ values at elevated RH.

The influence of RH on SOA formation is controversial (Hennigan et al., 2008; Fick et al., 2003; Edney et al., 2000; Saxena and Hildemann, 1996; Baker et al., 2001; Hasson et al., 2001; Cocker et al., 2001). Edney et al. (2000) and Seinfeld et al. (2001) reported an enhanced SOA formation of hydrophilic compounds under humid conditions and a lowered SOA formation of hydrophobic compounds. This is also supported by Saxena and Hildemann (1996), who found an enhanced partitioning of organic compounds with several hydroxyl groups at higher LWCs of the particles. This might lead to the conclusion that the $\mathrm{OH}$-radical oxidation of 1,3,5TMB results in the formation of hydrophobic compounds which showed an enhanced partitioning under dry conditions. Additionally, it can be speculated that the formation of oligomeric compounds can be enhanced at lower RH values resulting in higher $Y_{\mathrm{SOA}}$ due to the increasing conversion of the monomeric building blocks and their enhanced partitioning into the particle phase.

\subsection{Particulate methylglyoxal}

Methylglyoxal is reported in the literature as an important oxidation product of 1,3,5-TMB (Metzger et al., 2008; Healy et al., 2008; Cocker et al., 2001; Smith et al., 1999; Wyche et al., 2009; Baltensperger et al., 2005; Rickard et al., 2010; Kalberer et al., 2004; Yu et al., 1997; Kleindienst et al., 1999; Müller et al., 2012; Nishino et al., 2010; Hamilton et al., 2003; Tuazon et al., 1986; Bandow and Washida, 1985), with yields in the particle phase between 0.7 and $2 \%$.

The fraction of methylglyoxal in the particle phase in dependency on the reaction conditions is shown in Fig. 5a, with resulting fractions between $\approx 0.6$ and $\approx 2.2 \%$. With increasing RH the fraction decreases for both seed particles. Methylglyoxal has the highest fraction under dry conditions $\left(1.73 \pm 0.20 \%\right.$ and $2.17 \pm 0.20 \%$ for $\mathrm{NH}_{4} \mathrm{HSO}_{4}$ and
$\left.\left(\mathrm{NH}_{4}\right)_{2} \mathrm{SO}_{4} / \mathrm{H}_{2} \mathrm{SO}_{4}\right)$ and with $\left(\mathrm{NH}_{4}\right)_{2} \mathrm{SO}_{4} / \mathrm{H}_{2} \mathrm{SO}_{4}$ seed particles.

Healy et al. (2008) measured a contribution of methylglyoxal to SOA mass of $2.06 \pm 0.08 \%$ from the photooxidation of 1,3,5-TMB in the presence of $\mathrm{NO}_{x}$ at $\mathrm{RH}=50 \%$. In the present study a methylglyoxal fraction of $1.24 \pm 0.04 \%$ for $\mathrm{NH}_{4} \mathrm{HSO}_{4}$ seed particles and $0.80 \pm 0.08 \%$ for $\left(\mathrm{NH}_{4}\right)_{2} \mathrm{SO}_{4} / \mathrm{H}_{2} \mathrm{SO}_{4}$ seed particles was determined at $\mathrm{RH}=50 \%$. Thus, the contribution is slightly lower than measured by Healy et al. (2008). In comparison, Cocker et al. (2001) measured a particulate fraction of $0.72 \%$.

The dependency of particulate methylglyoxal on RH could be a result of the influence of $\mathrm{RH}$ on the partitioning from the gas phase into the particle phase or on further reactions in the particle phase forming oligomers. The formation of oligomeric compounds from methylglyoxal has been investigated in a number of studies (e.g. De Haan et al., 2009; Kalberer et al., 2004; Loeffler et al., 2006; Zhao et al., 2006; Sareen et al., 2010; Altieri et al., 2008).

\subsection{Heat-decomposable methylglyoxal oligomers}

A method was developed to determine the contribution of heat-decomposable methylglyoxal oligomers to the produced organic particle mass $\Delta \mathrm{M}$. The method is based on the thermal decomposition of the heat-decomposable methylglyoxal oligomers into monomers. Thus, the concentration of monomeric methylglyoxal was determined prior and after thermal decomposition. The concentrations were converted into the fraction of methylglyoxal oligomers of $\Delta \mathrm{M}$ using the molar mass of methylglyoxal $\left(M_{\mathrm{w}}=72.06 \mathrm{~g} \mathrm{~mol}^{-1}\right)$. An oligomer fraction of $\approx 2$ up to $\approx 8 \%$ was determined.

Figure $5 \mathrm{~b}$ shows the dependency of the detected heat-decomposable methylglyoxal oligomers on the relative humidity with $\mathrm{NH}_{4} \mathrm{HSO}_{4}$ and $\left(\mathrm{NH}_{4}\right)_{2} \mathrm{SO}_{4} / \mathrm{H}_{2} \mathrm{SO}_{4}$ seed particles. In the presence of $\mathrm{NH}_{4} \mathrm{HSO}_{4}$ seed particles the highest oligomer fraction $(8.2 \pm 0.7 \%)$ can be observed with $\mathrm{RH}=0 \%$, whereas in the presence 
of $\left(\mathrm{NH}_{4}\right)_{2} \mathrm{SO}_{4} / \mathrm{H}_{2} \mathrm{SO}_{4}$ seed particles the oligomer fraction is the lowest $(2.1 \pm 0.4 \%)$ under dry conditions $(\mathrm{RH}=0 \%)$. A possible explanation for the opposite trend of the oligomer fractions with $\mathrm{RH}$ between $\mathrm{NH}_{4} \mathrm{HSO}_{4}$ and $\left(\mathrm{NH}_{4}\right)_{2} \mathrm{SO}_{4} / \mathrm{H}_{2} \mathrm{SO}_{4}$ seed particles could be different oligomer formation mechanism caused by different seed particle acidity. The type of accretion reaction might change with $\mathrm{pH}$ (Yasmeen et al., 2010). In Table 5 the $\mathrm{pH}$ of the seed particles was calculated with E-AIM. $\mathrm{NH}_{4} \mathrm{HSO}_{4}$ particles have $\mathrm{pH}=0.1$ and 1.2 at $\mathrm{RH}=50$ and $75 \%$. In comparison $\left(\mathrm{NH}_{4}\right)_{2} \mathrm{SO}_{4} / \mathrm{H}_{2} \mathrm{SO}_{4}$ seed particles are less acidic $(\mathrm{pH}=4.0$ at $\mathrm{RH}=50 \%$ and $\mathrm{pH}=4.2$ at $\mathrm{RH}=75 \%$ ).

It was postulated by Yasmeen et al. (2010) that a lower $\mathrm{pH}(\mathrm{pH}<3.5)$ favour acetal/hemiacetal formation whereas at high $\mathrm{pH}(\mathrm{pH}=4-5)$ aldol condensation are more relevant. This has been supported by Sedehi et al. (2013) and Sareen et al. (2010).

Thus, in the presence of strong acidic $\mathrm{NH}_{4} \mathrm{HSO}_{4}$ seed particles acetal/hemiacetal formation might be the favoured oligomer formation mechanism. Oligomerisation via acetal/hemiacetal formation occurs under a reversible water loss (Yasmeen et al., 2010). As higher RH values in the aerosol chamber LEAK lead to higher LWCs of the seed particles (Table 5) the chemical equilibrium of the reaction shifts towards the precursor compound, resulting in a lower methylglyoxal oligomer fraction (Kalberer et al., 2004; Liggio et al., 2005). In addition, the $\mathrm{pH}$ of $\mathrm{NH}_{4} \mathrm{HSO}_{4}$ particles decreases with decreasing RH (Table 5); thus, acid-catalysed acetal/hemiacetal formation might be enhanced under dry conditions due to a lower $\mathrm{pH}$ (Liggio et al., 2005).

In the presence of $\left(\mathrm{NH}_{4}\right)_{2} \mathrm{SO}_{4} / \mathrm{H}_{2} \mathrm{SO}_{4}$ seed particles the oligomer fraction increases with increasing RH (Fig. 5b). As has been mentioned, aldol condensation can be assumed as the favoured accretion reaction under these conditions (Yasmeen et al., 2010). Aldol condensation includes aldol addition as a first step, followed by a loss of water. The loss of water is irreversible; thus, the aldol condensation will not be inhibited by higher LWC of the seed particles.

Other accretion reactions can contribute to the formation of heat-decomposable methylglyoxal oligomers with $\left(\mathrm{NH}_{4}\right)_{2} \mathrm{SO}_{4} / \mathrm{H}_{2} \mathrm{SO}_{4}$ seed particles as well. Altieri et al. (2008) detected products formed through acid-catalysed esterification at $\mathrm{pH} \approx 4$. This equilibrium reaction involves the reversible loss of water, as was reported for acetal/hemiacetal formation (Lim et al., 2010). Thus, it can be expected that with higher LWCs the contribution of esterification reactions to oligomer formation decreases due to the shift of the equilibrium towards the monomers.

Imidazole formation was also postulated as a possible oligomer-formation mechanism for methylglyoxal (Sedehi et al., 2013; De Haan et al., 2011). It was found that imidazole formation is of minor importance compared to aldol condensation (Sedehi et al., 2013). However, imidazole formation also involves a reversible loss of water; thus, it does not pro- vide a feasible explanation for the higher oligomer fraction at higher $\mathrm{RH}$ with $\left(\mathrm{NH}_{4}\right)_{2} \mathrm{SO}_{4} / \mathrm{H}_{2} \mathrm{SO}_{4}$ seed particles.

Radical-radical reactions are also postulated as a possible reaction pathway to form oligomers (Schaefer et al., 2015; Lim et al., 2010, 2013; Rincon et al., 2009; Sun et al., 2010). Radical-radical reactions of methylglyoxal might occur following the $\mathrm{H}$-atom abstraction of methylglyoxal with $\mathrm{OH}$ radicals and a subsequent recombination of the resulting alkyl radicals (as discussed for glyoxal in Schaefer et al., 2015). The contribution of radical-radical reactions to oligomer formation is not well understood as the reaction of alkyl radicals with oxygen clearly tends to suppress this pathway. Nevertheless, it can be expected that, with higher LWCs of the seed particles and thus a higher reaction volume, the absolute amount of methylglyoxal in the particle phase might increase, but not its particle-phase concentrations. For aerosol particle systems, ionic strength effects (Herrmann et al., 2015) are able to influence the uptake of methylglyoxal into the particle phase as well. Waxman et al. (2015) observed a salting-out effect for methylglyoxal for all investigated seed particles at higher ionic strengths.

Low $\mathrm{pH}$ combined with high solute concentrations, as calculated for the present aerosol particles, can trigger isomerisation (or switching) reactions as discussed by Herrmann et al. (2015). Overall, a clear discussion on how radical-radical reaction might be affected by increasing LWC (through increasing $\mathrm{RH}$ ) and by $\mathrm{pH}$ is difficult at the current level of knowledge.

In summary, the present study provides a reliable quantification method for heat-decomposable methylglyoxal oligomers formed by 1,3,5-TMB oxidation. The fraction of oligomeric substances formed solely by methylglyoxal oligomerisation varied depending on $\mathrm{RH}$ and seed particle acidity between 2 and $8 \%$, which is lower than the values determined by Kalberer et al. (2004) and Baltensperger et al. (2005) (varying between 50 and $80 \%$ ). In the present study only heat-decomposable methylglyoxal oligomers were quantified; thus, there might be not heatdecomposable methylglyoxal oligomers or oligomers originating from other monomers than methylglyoxal, which were not determined in the present study, leading to lower oligomer fractions of $\Delta \mathrm{M}$ compared to the literature. The obtained data are not fully conclusive and studies in the literature are often contradictory. Thus, more experiments are necessary to get a clearer picture about the influence of RH and particle-phase acidity on oligomer formation and to explain the non-linear relation between the oligomer fraction and RH.

\section{Summary}

In the present study a method was developed to quantify oligomers formed from methylglyoxal. The method is based on the thermal decomposition of heat-decomposable methyl- 
glyoxal oligomers into monomers. The formed methylglyoxal monomers were detected with PFBHA derivatisation and GC/MS analysis. The influence of heating time, $\mathrm{pH}$ and heating temperature on the decomposition of heatdecomposable methylglyoxal oligomers was systematically investigated. The best result was achieved with a heating time of $24 \mathrm{~h}$ at $100^{\circ} \mathrm{C}$ and $\mathrm{pH}=1$. The method was applied to heat-decomposable methylglyoxal oligomers formed during the oxidation of $1,3,5-\mathrm{TMB}$, resulting in an oligomer fraction of up to $\approx 8 \%$. A contradictory dependency of the oligomer fraction under varying $\mathrm{RH}$ with $\mathrm{NH}_{4} \mathrm{HSO}_{4}$ and $\left(\mathrm{NH}_{4}\right)_{2} \mathrm{SO}_{4} / \mathrm{H}_{2} \mathrm{SO}_{4}$ seed particles was found, which might be caused by different oligomer formation mechanisms.

Overall, the present method provides an important step revealing the amount of oligomers present in the particle phase, their tentative formation mechanism, and their importance for aqSOA formation.

Data availability. For access to the data set used in the present study, please contact the corresponding author.

Competing interests. The authors declare that they have no conflict of interest.

Acknowledgements. This study was supported by the scholarship programme of the German Federal Environmental Foundation (Deutsche Bundesstiftung Umwelt, DBU; grant number 20013/244).

Edited by: F. Keutsch

Reviewed by: two anonymous referees

\section{References}

Alfarra, M. R., Paulsen, D., Gysel, M., Garforth, A. A., Dommen, J., Prevot, A. S. H., Worsnop, D. R., Baltensperger, U., and Coe, H.: A mass spectrometric study of secondary organic aerosols formed from the photooxidation of anthropogenic and biogenic precursors in a reaction chamber, Atmos. Chem. Phys., 6, 52795293, doi:10.5194/acp-6-5279-2006, 2006.

Altieri, K. E., Seitzinger, S. P., Carlton, A. G., Turpin, B. J., Klein, G. C., and Marshall, A. G.: Oligomers formed through in-cloud methylglyoxal reactions: Chemical composition, properties, and mechanisms investigated by ultra-high resolution FT-ICR mass spectrometry, Atmos. Environ., 42, 1476-1490, doi:10.1016/j.atmosenv.2007.11.015, 2008.

Andrews, E.,and Larson, S. M.: Effect of surfactant layers on the size changes of aerosol-particles as a function of relative-humidity, Environ. Sci. Technol., 27, 857-865, doi:10.1021/es00042a007, 1993.

Angove, D. E., Fookes, C. J. R., Hynes, R. G., Walters, C. K., and Azzi, M.: The characterisation of secondary organic aerosol formed during the photodecomposition of 1,3-butadiene in air containing nitric oxide, Atmos. Environ., 40, 4597-4607, doi:10.1016/j.atmosenv.2006.03.046, 2006.

Bahreini, R., Keywood, M. D., Ng, N. L., Varutbangkul, V., Gao, S., Flagan, R. C., Seinfeld, J. H., Worsnop, D. R., and Jimenez, J. L.: Measurements of secondary organic aerosol from oxidation of cycloalkenes, terpenes, and m-xylene using an Aerodyne aerosol mass spectrometer, Environ. Sci. Technol., 39, 5674 5688, doi:10.1021/es048061a, 2005.

Baker, J., Aschmann, S. M., Arey, J., and Atkinson, R.: Reactions of stabilized Criegee intermediates from the gas-phase reactions of $\mathrm{O}_{3}$ with selected alkenes, Int. J. Chem. Kinet., 34, 73-85, 2001.

Baltensperger, U., Kalberer, M., Dommen, J., Paulsen, D., Alfarra, M. R., Coe, H., Fisseha, R., Gascho, A., Gysel, M., Nyeki, S., Sax, M., Steinbacher, M., Prevot, A. S. H., Sjogren, S., Weingartner, E., and Zenobi, R.: Secondary organic aerosols from anthropogenic and biogenic precursors, Faraday Discuss., 130, 265-278, doi:10.1039/b417367h, 2005.

Bandow, H. and Washida, N.: Ring-cleavage reactions of aromatic hydrocarbons studied by FT-IR spectroscopy. III. Photooxidation of 1,2,3-,1,2,4-, and 1,3,5-trimethylbenzene in the NOx-air system, B. Chem. Soc. Jpn., 58, 2549-2555, doi:10.1246/bcsj.58.2549, 1985.

Barsanti, K. C. and Pankow, J. F.: Thermodynamics of the formation of atmospheric organic particulate matter by accretion reactions - 2. Dialdehydes, methylglyoxal, and diketones, Atmos. Environ., 39, 6597-6607, doi:10.1016/j.atmosenv.2005.07.056, 2005.

Berndt, T. and Böge, O.: Formation of phenol and carbonyls from the atmospheric reaction of $\mathrm{OH}$ radicals with benzene, Phys. Chem. Chem. Phys., 8, 1205-1214, doi:10.1039/b514148f, 2006.

Bertram, A. K., Martin, S. T., Hanna, S. J., Smith, M. L., Bodsworth, A., Chen, Q., Kuwata, M., Liu, A.; You, Y., and Zorn, S. R.: Predicting the relative humidities of liquid-liquid phase separation, efflorescence, and deliquescence of mixed particles of ammonium sulfate, organic material, and water using the organic-to-sulfate mass ratio of the particle and the oxygen-to-carbon elemental ratio of the organic component, Atmos. Chem. Physi., 11, 10995-11006, doi:10.5194/acp-1110995-2011, 2011.

Birdsall, A. W., Zentner, C. A., and Elrod, M. J.: Study of the kinetics and equilibria of the oligomerization reactions of 2-methylglyceric acid, Atmos. Chem. Phys., 13, 3097-3109, doi:10.5194/acp-13-3097-2013, 2013.

Bones, D. L., Henricksen, D. K., Mang, S. A., Gonsior, M., Bateman, A. P., Nguyen, T. B., Cooper, W. J., and Nizkorodov, S. A.: Appearance of strong absorbers and fluorophores in limonene$\mathrm{O}_{3}$ secondary organic aerosol due to $\mathrm{NH}_{4}^{+}$-mediated chemical aging over long time scales, J. Geophys. Res.-Atmos., 115, 114, doi:10.1029/2009jd012864, 2010.

Cao, G. and Jang, M.: Effects of particle acidity and UV light on secondary organic aerosol formation from oxidation of aromatics in the absence of $\mathrm{NO}_{x}$, Atmos. Environ., 41, 7603-7613, doi:10.1016/j.atmosenv.2007.05.034, 2007.

Casale, M. T., Richman, A. R., Elrod, M. J., Garland, R. M., Beaver, M. R., and Tolbert, M. A.: Kinetics of acid-catalyzed aldol condensation reactions of aliphatic aldehydes, Atmos. Environ., 41, 6212-6224, doi:10.1016/j.atmosenv.2007.04.002, 2007.

Chen, Y. Y. and Lee, W. M. G.: Hygroscopic properties of inorganicsalt aerosol with surface-active organic compounds, Chemo- 
sphere, 38, 2431-2448, doi:10.1016/s0045-6535(98)00436-6, 1999.

Clegg, S. L., Brimblecombe, P., and Wexler, A. S.: Thermodynamic model of the system $\mathrm{H}^{+}-\mathrm{NH}_{4}^{+}-\mathrm{SO}_{4}^{2}-\mathrm{NO}_{3}^{-}-\mathrm{H}_{2} \mathrm{O}$ at tropospheric temperatures, J. Phys. Chem. A, 102, 2137-2154, doi:10.1021/jp973042r, 1998.

Cocker, D. R., Mader, B. T., Kalberer, M., Flagan, R. C., and Seinfeld, J. H.: The effect of water on gas-particle partitioning of secondary organic aerosol: II. m-xylene and 1,3,5trimethylbenzene photooxidation systems, Atmos. Environ., 35, 6073-6085, doi:10.1016/s1352-2310(01)00405-8, 2001.

Cziczo, D. J., Nowak, J. B., Hu, J. H., and Abbatt, J. P. D.: Infrared spectroscopy of model tropospheric aerosols as a function of relative humidity: Observation of deliquescence and crystallization, J. Geophys. Res.-Atmos., 102, 18843-18850, doi:10.1029/97jd01361, 1997.

De Haan, D. O., Corrigan, A. L., Tolbert, M. A., Jimenez, J. L., Wood, S. E., and Turley, J. J.: Secondary organic aerosol formation by self-reactions of methylglyoxal and glyoxal in evaporating droplets, Environ. Sci. Technol., 43, 8184-8190, doi:10.1021/es902152t, 2009.

De Haan, D. O., Hawkins, L. N., Kononenko, J. A., Turley, J. J., Corrigan, A. L., Tolbert, M. A., and Jimenez, J. L.: Formation of Nitrogen-Containing Oligomers by Methylglyoxal and Amines in Simulated Evaporating Cloud Droplets, Environ. Sci. Technol., 45, 984-991, doi:10.1021/es102933x, 2011.

Denkenberger, K. A., Moffet, R. C., Holecek, J. C., Rebotier, T. P., and Prather, K. A.: Real-time, single-particle measurements of oligomers in aged ambient aerosol particles, Environ. Sci. Technol., 41, 5439-5446, doi:10.1021/es0703291, 2007.

Dommen, J., Metzger, A., Duplissy, J., Kalberer, M., Alfarra, M. R., Gascho, A., Weingartner, E., Prevot, A. S. H., Verheggen, B., and Baltensperger, U.: Laboratory observation of oligomers in the aerosol from isoprene/ $\mathrm{NO}_{x}$ photooxidation, Geophys. Res. Lett., 33, 1-5, doi:10.1029/2006GL026523, 2006.

Drozd, G. T. and McNeill, V. F.: Organic matrix effects on the formation of light-absorbing compounds from alpha-dicarbonyls in aqueous salt solution, Environ. Sci.-Proc. Imp., 16, 741-747, doi:10.1039/c3em00579h, 2014.

Edney, E. O., Driscoll, D. J., Speer, R. E., Weathers, W. S., Kleindienst, T. E., Li, W., and Smith, D. F.: Impact of aerosol liquid water on secondary organic aerosol yields of irradiated toluene/propylene/ $\mathrm{NO}_{x} /\left(\mathrm{NH}_{2}^{4}\right) \mathrm{SO}_{4}$ /air mixtures, Atmos. Environ., 34, 3907-3919, doi:10.1016/s1352-2310(00)00174-6, 2000.

Fick, J., Pommer, L., Nilsson, C., and Andersson, B.: Effect of $\mathrm{OH}$ radicals, relative humidity, and time on the composition of the products formed in the ozonolysis of alpha-pinene, Atmos. Environ., 37, 4087-4096, doi:10.1016/s1352-2310(03)00522-3, 2003

Gao, S., Keywood, M., Ng, N. L., Surratt, J., Varutbangkul, V., Bahreini, R., Flagan, R. C., and Seinfeld, J. H.: Low-molecularweight and oligomeric components in secondary organic aerosol from the ozonolysis of cycloalkenes and alpha-pinene, J. Phys. Chem. A, 108, 10147-10164, doi:10.1021/jp047466e, 2004.

Garland, R. M., Elrod, M. J., Kincaid, K., Beaver, M. R., Jimenez, J. L., and Tolbert, M. A.: Acid-catalyzed reactions of hexanal on sulfuric acid particles: Identification of reaction products, Atmos.
Environ., 40, 6863-6878, doi:10.1016/j.atmosenv.2006.07.009, 2006.

Gee, I. L. and Sollars, C. J.: Ambient air levels of volatile organic compounds in Latin American and Asian cities, Chemosphere, 36, 2497-2506, doi:10.1016/S0045-6535(97)10217-X, 1998.

Gutbrod, R., Schindler, R. N., Kraka, E., and Cremer, D.: Formation of $\mathrm{OH}$ radicals in the gas phase ozonolysis of alkenes: the unexpected role of carbonyl oxides, Chem. Phys. Lett., 252, 221-229, doi:10.1016/0009-2614(96)00126-1, 1996.

Hall, W. A. and Johnston, M. V.: Oligomer Formation Pathways in Secondary Organic Aerosol from MS and MS/MS Measurements with High Mass Accuracy and Resolving Power, J. Am. Soc. Mass Spectrom., 23, 1097-1108, doi:10.1007/s13361-0120362-6, 2012.

Hallquist, M., Wenger, J. C., Baltensperger, U., Rudich, Y., Simpson, D., Claeys, M., Dommen, J., Donahue, N. M., George, C., Goldstein, A. H., Hamilton, J. F., Herrmann, H., Hoffmann, T., Iinuma, Y., Jang, M., Jenkin, M. E., Jimenez, J. L., KiendlerScharr, A., Maenhaut, W., McFiggans, G., Mentel, T. F., Monod, A., Prevot, A. S. H., Seinfeld, J. H., Surratt, J. D., Szmigielski, R., and Wildt, J.: The formation, properties and impact of secondary organic aerosol: current and emerging issues, Atmos. Chem. Phys., 9, 5155-5236, doi:10.5194/acp-9-5155-2009, 2009.

Hamilton, J. F., Lewis, A. C., Bloss, C., Wagner, V., Henderson, A. P., Golding, B. T., Wirtz, K., Martin-Reviejo, M., and Pilling, M. $\mathrm{J}$.: Measurements of photo-oxidation products from the reaction of a series of alkyl-benzenes with hydroxyl radicals during EXACT using comprehensive gas chromatography, Atmos. Chem. Phys., 3, 1999-2014, doi:10.5194/acp-3-1999-2003, 2003.

Hamilton, J. F., Lewis, A. C., Reynolds, J. C., Carpenter, L. J., and Lubben, A.: Investigating the composition of organic aerosol resulting from cyclohexene ozonolysis: low molecular weight and heterogeneous reaction products, Atmos. Chem. Phys., 6, 49734984, doi:10.5194/acp-6-4973-2006, 2006.

Hasson, A. S., Orzechowska, G., and Paulson, S. E.: Production of stabilized Criegee intermediates and peroxides in the gas phase ozonolysis of alkenes 1. Ethene, trans-2-butene, and 2,3dimethyl-2-butene, J. Geophys. Res.-Atmos., 106, 34131-34142, doi:10.1029/2001jd000597, 2001.

Hastings, W. P., Koehler, C. A., Bailey, E. L., and De Haan, D. O.: Secondary organic aerosol formation by glyoxal hydration and oligomer formation: Humidity effects and equilibrium shifts during analysis, Environ. Sci. Technol., 39, 8728-8735, doi:10.1021/es0504461, 2005.

Healy, R. M., Wenger, J. C., Metzger, A., Duplissy, J., Kalberer, M., and Dommen, J.: Gas/particle partitioning of carbonyls in the photooxidation of isoprene and 1,3,5-trimethylbenzene, Atmos. Chem. Phys., 8, 3215-3230, doi:10.5194/acp-8-3215-2008, 2008.

Heaton, K. J., Dreyfus, M. A., Wang, S., and Johnston, M. V.: Oligomers in the early stage of biogenic secondary organic aerosol formation and growth, Environ. Sci. Technol., 41, 61296136, doi:10.1021/es070314n, 2007.

Hennigan, C. J., Bergin, M. H., Dibb, J. E., and Weber, R. J.: Enhanced secondary organic aerosol formation due to water uptake by fine particles, Geophys. Res. Lett., 35, 1-5, doi:10.1029/2008g1035046, 2008.

Herrmann, H., Schaefer, T., Tilgner, A., Styler, S. A., Weller, C., Teich, M., and Otto, T.: Tropospheric aqueous-phase chemistry: 
Kinetics, mechanisms, and its coupling to a changing gas phase, Chem. Rev., 115, 4259-4334, doi:10.1021/cr500447k, 2015.

Holmes, B. J. and Petrucci, G. A.: Water-soluble oligomer formation from acid-catalyzed reactions of levoglucosan in proxies of atmospheric aqueous aerosols, Environ. Sci. Technol., 40, 49834989, doi:10.1021/es060646c, 2006.

Huang, M. Q., Hu, C. J., Guo, X. Y., Gu, X. J., Zhao, W. X., Wang, Z. Y., Fang, L., and Zhang, W. J.: Chemical composition of gas and particle-phase products of $\mathrm{OH}$-initiated oxidation of 1,3,5-trimethylbenzene, Atmos. Poll. Res., 5, 73-78, doi:10.5094/APR.2014.009, 2014

Huang, M. Q., Lin, Y. H., Huang, X. Y., Liu, X. Q., Guo, X. Y., Hu, C. J., Zhao, W. X., Gu, X. J., Fang, L., and Zhang, W. J.: Experimental study of particulate products for aging of 1,3,5trimethylbenzene secondary organic aerosol, Atmos. Poll. Res., 6, 209-219, doi:10.5094/APR.2015.025, 2015.

Iinuma, Y., Böge, O., Gnauk, T., and Herrmann, H.: Aerosolchamber study of the $\alpha$-pinene $/ \mathrm{O}_{3}$ reaction: influence of particle acidity on aerosol yields and products, Atmos. Environ., 38, 761-773, doi:10.1016/j.atmosenv.2003.10.015, 2004.

Jang, M., Lee, S., and Kamens, R. M.: Organic aerosol growth by acid-catalyzed heterogeneous reactions of octanal in a flow reactor, Atmos. Environ., 37, 2125-2138, doi:10.1016/s13522310(03)00077-3, 2003.

Jang, M. S. and Kamens, R. M.: Atmospheric secondary aerosol formation by heterogeneous reactions of aldehydes in the presence of a sulfuric acid aerosol catalyst, Environ. Sci. Technol., 35, 4758-4766, doi:10.1021/es010790s, 2001.

Kahnt, A., Iinuma, Y., Böge, O., Mutzel, A., and Herrmann, H.: Denuder sampling techniques for the determination of gas-phase carbonyl compounds: A comparison and characterisation of in situ and ex situ derivatisation methods, J. Chromatogr. B, 879, 1402-1411, doi:10.1016/j.jchromb.2011.02.028, 2011.

Kalberer, M., Paulsen, D., Sax, M., Steinbacher, M., Dommen, J., Prevot, A. S. H., Fisseha, R., Weingartner, E., Frankevich, V., Zenobi, R., and Baltensperger, U.: Identification of polymers as major components of atmospheric organic aerosols, Science, 303, 1659-1662, doi:10.1126/science.1092185, 2004.

Kalberer, M., Sax, M., and Samburova, V.: Molecular size evolution of oligomers in organic aerosols collected in urban atmospheres and generated in a smog chamber, Environ. Sci. Technol., 40, 5917-5922, doi:10.1021/es0525760, 2006.

Khoder, M. I.: Ambient levels of volatile organic compounds in the atmosphere of Greater Cairo, Atmos. Environ., 41, 554-566, doi:10.1016/j.atmosenv.2006.08.051, 2007.

Kleindienst, T. E., Smith, D. F., Li, W., Edney, E. O., Driscoll, D. J., Speer, R. E., and Weathers, W. S.: Secondary organic aerosol formation from the oxidation of aromatic hydrocarbons in the presence of dry submicron ammonium sulfate aerosol, Atmos. Environ., 33, 3669-3681, doi:10.1016/S1352-2310(99)00121-1, 1999.

Krizner, H. E., De Haan, D. O., and Kua, J.: Thermodynamics and Kinetics of Methylglyoxal Dimer Formation: A Computational Study, J. Phys. Chem. A, 113, 6994-7001, doi:10.1021/jp903213k, 2009.

Kua, J., Galloway, M. M., Millage, K. D., Avila, J. E., and De Haan, D. O.: Glycolaldehyde Monomer and Oligomer Equilibria in Aqueous Solution: Comparing Computational Chem- istry and NMR Data, J. Phys. Chem. A, 117, 2997-3008, doi:10.1021/jp312202j, 2013.

Kundu, S., Fisseha, R., Putman, A. L., Rahn, T. A., and Mazzoleni, L. R.: High molecular weight SOA formation during limonene ozonolysis: insights from ultrahigh-resolution FT-ICR mass spectrometry characterization, Atmos. Chem. Phys., 12, 5523-5536, doi:10.5194/acp-12-5523-2012, 2012.

Liggio, J., Li, S. M., and McLaren, R.: Heterogeneous reactions of glyoxal on particulate matter: Identification of acetals and sulfate esters, Environ. Sci. Technol., 39, 1532-1541, doi:10.1021/es048375y, 2005.

Lightstone, J. M., Onasch, T. B., Imre, D., and Oatis, S.: Deliquescence, efflorescence, and water activity in ammonium nitrate and mixed ammonium nitrate/succinic acid microparticles, J. Phys. Chem. A, 104, 9337-9346, doi:10.1021/jp002137h, 2000.

Lim, Y. B. and Turpin, B. J.: Laboratory evidence of organic peroxide and peroxyhemiacetal formation in the aqueous phase and implications for aqueous $\mathrm{OH}$, Atmo. Chem. Phys., 15, 12867 12877, doi:10.5194/acp-15-12867-2015, 2015.

Lim, Y. B., Tan, Y., Perri, M. J., Seitzinger, S. P., and Turpin, B. J.: Aqueous chemistry and its role in secondary organic aerosol (SOA) formation, Atmos. Chem. Phys., 10, 1052110539, doi:10.5194/acp-10-10521-2010, 2010.

Lim, Y. B., Tan, Y., and Turpin, B. J.: Chemical insights, explicit chemistry, and yields of secondary organic aerosol from $\mathrm{OH}$ radical oxidation of methylglyoxal and glyoxal in the aqueous phase, Atmos. Chem. Phys., 13, 8651-8667, doi:10.5194/acp-13-86512013, 2013.

Liu, Y., Shao, M., Lu, S., Chang, C.-C., Wang, J.-L., and Chen, G.: Volatile Organic Compound (VOC) measurements in the Pearl River Delta (PRD) region, China, Atmos. Chem. Phys., 8, 15311545, doi:10.5194/acp-8-1531-2008, 2008.

Loeffler, K. W., Koehler, C. A., Paul, N. M., and De Haan, D. O.: Oligomer formation in evaporating aqueous glyoxal and methyl glyoxal solutions, Environ. Sci. Technol., 40, 6318-6323, doi:10.1021/es060810w, 2006.

Metzger, A., Dommen, J., Gaeggeler, K., Duplissy, J., Prevot, A. S. H., Kleffmann, J., Elshorbany, Y., Wisthaler, A., and Baltensperger, U.: Evaluation of 1,3,5 trimethylbenzene degradation in the detailed tropospheric chemistry mechanism, MCMv3.1, using environmental chamber data, Atmos. Chem. Phys., 8, 6453-6468, doi:10.5194/acp-8-6453-2008, 2008.

Müller, L., Reinnig, M.-C., Warnke, J., and Hoffmann, Th.: Unambiguous identification of esters as oligomers in secondary organic aerosol formed from cyclohexene and cyclohexene $/ \alpha$ pinene ozonolysis, Atmos. Chem. Phys., 8, 1423-1433, doi:10.5194/acp-8-1423-2008, 2008.

Müller, M., Graus, M., Wisthaler, A., Hansel, A., Metzger, A., Dommen, J., and Baltensperger, U.: Analysis of high mass resolution PTR-TOF mass spectra from 1,3,5trimethylbenzene (TMB) environmental chamber experiments, Atmos. Chem. Phys., 12, 829-843, doi:10.5194/acp-12-8292012, 2012.

Mutzel, A., Rodigast, M., Iinuma, Y., Boge, O., and Herrmann, H.: Monoterpene SOA - Contribution of first-generation oxidation products to formation and chemical composition, Atmos. Environ., 130, 136-144, doi:10.1016/j.atmosenv.2015.10.080, 2016.

Nemet, I., Vikic-Topic, D., and Varga-Defterdarovic, L.: Spectroscopic studies of methylglyoxal in water and dimethylsulfoxide, 
Bioorg. Chem., 32, 560-570, doi:10.1016/j.bioorg.2004.05.008, 2004.

Nguyen, T. B., Roach, P. J., Laskin, J., Laskin, A., and Nizkorodov, S. A.: Effect of humidity on the composition of isoprene photooxidation secondary organic aerosol, Atmos. Chem. Phys., 11, 6931-6944, doi:10.5194/acp-11-6931-2011, 2011.

Nishino, N., Arey, J., and Atkinson, R.: Formation yields of glyoxal and methylglyoxal from the gas-phase $\mathrm{OH}$ radical-initiated reactions of toluene, xylenes, and trimethylbenzenes as a function of $\mathrm{NO}_{2}$ concentration, J. Phys. Chem. A, 114, 10140-10147, doi:10.1021/jp105112h, 2010.

Noziere, B. and Cordova, A.: A kinetic and mechanistic study of the amino acid catalyzed aldol condensation of acetaldehyde in aqueous and salt solutions, J. Phys. Chem. A, 112, 2827-2837, doi:10.1021/jp7096845, 2008.

Noziere, B. and Esteve, W.: Organic reactions increasing the absorption index of atmospheric sulfuric acid aerosols, Geophys. Res. Lett., 32, 1-5, doi:10.1029/2004g1021942, 2005.

Noziere, B., Dziedzic, P., and Cordova, A.: Formation of secondary light-absorbing "fulvic-like" oligomers: A common process in aqueous and ionic atmospheric particles?, Geophys. Res. Lett., 34, 1-5, doi:10.1029/2007GL031300, 2007.

Noziere, B., Dziedzic, P., and Cordova, A.: Inorganic ammonium salts and carbonate salts are efficient catalysts for aldol condensation in atmospheric aerosols, Phys. Chem. Chem. Phys., 12, 3864-3872, doi:10.1039/B924443C, 2010.

Odum, J. R., Jungkamp, T. P. W., Griffin, R. J., Forstner, H. J. L., Flagan, R. C., and Seinfeld, J. H.: Aromatics, reformulated gasoline, and atmospheric organic aerosol formation, Environ. Sci. Technol., 31, 1890-1897, doi:10.1021/es9605351, 1997.

Paulot, F., Crounse, J. D., Kjaergaard, H. G., Kurten, A., St Clair, J. M., Seinfeld, J. H., and Wennberg, P. O.: Unexpected Epoxide Formation in the Gas-Phase Photooxidation of Isoprene, Science, 325, 730-733, doi:10.1126/science.1172910, 2009.

Paulsen, D., Dommen, J., Kalberer, M., Prevot, A. S. H., Richter, R., Sax, M., Steinbacher, M., Weingartner, E., and Baltensperger, U.: Secondary organic aerosol formation by irradiation of 1,3,5trimethylbenzene- $\mathrm{NO}_{x}-\mathrm{H}_{2} \mathrm{O}$ in a new reaction chamber for atmospheric chemistry and physics, Environ. Sci. Technol., 39, 2668-2678, doi:10.1021/es0489137, 2005.

Prenni, A. J., De Mott, P. J., and Kreidenweis, S. M.: Water uptake of internally mixed particles containing ammonium sulfate and dicarboxylic acids, Atmos. Environ., 37, 4243-4251, doi:10.1016/s1352-2310(03)00559-4, 2003.

Reinhardt, A., Emmenegger, C., Gerrits, B., Panse, C., Dommen, J., Baltensperger, U., Zenobi, R., and Kalberer, M.: Ultrahigh mass resolution and accurate mass measurements as a tool to characterize oligomers in secondary organic aerosols, Anal. Chem., 79, 4074-4082, doi:10.1021/ac062425v, 2007.

Rickard, A. R., Wyche, K. P., Metzger, A., Monks, P. S., Ellis, A. M., Dommen, J., Baltensperger, U., Jenkin, M. E., and Pilling, M. J.: Gas phase precursors to anthropogenic secondary organic aerosol: Using the Master Chemical Mechanism to probe detailed observations of 1,3,5trimethylbenzene photo-oxidation, Atmos. Environ., 44, 54235433, doi:10.1016/j.atmosenv.2009.09.043, 2010.

Rincon, A. G., Guzman, M. I., Hoffmann, M. R., and Colussi, A. J.: Optical absorptivity versus molecular composition of model organic aerosol matter, J. Phys. Chem. A, 113, 10512-10520, doi:10.1021/jp904644n, 2009.

Rodigast, M., Mutzel, A., Iinuma, Y., Haferkorn, S., and Herrmann, H.: Characterisation and optimisation of a sample preparation method for the detection and quantification of atmospherically relevant carbonyl compounds in aqueous medium, Atmos. Meas. Tech., 8, 2409-2416, doi:10.5194/amt-8-2409-2015, 2015.

Sadezky, A., Chaimbault, P., Mellouki, A., Römpp, A., Winterhalter, R., Le Bras, G., and Moortgat, G. K.: Formation of secondary organic aerosol and oligomers from the ozonolysis of enol ethers, Atmos. Chem. Phys., 6, 5009-5024, doi:10.5194/acp-6-50092006, 2006.

Sareen, N., Schwier, A. N., Shapiro, E. L., Mitroo, D., and McNeill, V. F.: Secondary organic material formed by methylglyoxal in aqueous aerosol mimics, Atmos. Chem. Phys., 10, 997-1016, doi:10.5194/acp-10-997-2010, 2010.

Sato, K., Takami, A., Kato, Y., Seta, T., Fujitani, Y., Hikida, T., Shimono, A., and Imamura, T.: AMS and LC/MS analyses of SOA from the photooxidation of benzene and 1,3,5-trimethylbenzene in the presence of $\mathrm{NO}_{x}$ : effects of chemical structure on SOA aging, Atmos. Chem. Phys., 12, 4667-4682, doi:10.5194/acp-124667-2012, 2012.

Saukko, E., Lambe, A. T., Massoli, P., Koop, T., Wright, J. P., Croasdale, D. R., Pedernera, D. A., Onasch, T. B., Laaksonen, A., Davidovits, P., Worsnop, D. R., and Virtanen, A.: Humiditydependent phase state of SOA particles from biogenic and anthropogenic precursors, Atmos. Chem. Phys., 12, 7517-7529, doi:10.5194/acp-12-7517-2012, 2012.

Saxena, P. and Hildemann, L. M.: Water-soluble organics in atmospheric particles: A critical review of the literature and application of thermodynamics to identify candidate compounds, J. Atmos. Chem., 24, 57-109, doi:10.1007/bf00053823, 1996.

Schaefer, T., van Pinxteren, D., and Herrmann, H.: Multiphase chemistry of glyoxal: Revised kinetics of the alkyl radical reaction with molecular oxygen and the reaction of Glyoxal with $\mathrm{OH}, \mathrm{NO}_{3}$, and $\mathrm{SO}_{4}^{-}$in aqueous solution, Environ. Sci. Technol., 49, 343-350, doi:10.1021/es505860s, 2015.

Schwier, A. N., Sareen, N., Mitroo, D., Shapiro, E. L., and McNeill, V. F.: Glyoxal-Methylglyoxal Cross-Reactions in Secondary Organic Aerosol Formation, Environ. Sci. Technol., 44, 6174-6182, doi:10.1021/es101225q, 2010.

Sedehi, N., Takano, H., Blasic, V. A., Sullivan, K. A., and De Haan, D. O.: Temperature- and $\mathrm{pH}$-dependent aqueous-phase kinetics of the reactions of glyoxal and methylglyoxal with atmospheric amines and ammonium sulfate, Atmos. Environ., 77, 656-663, doi:10.1016/j.atmosenv.2013.05.070, 2013.

Seinfeld, J. H., Erdakos, G. B., Asher, W. E., and Pankow, J. F.: Modeling the formation of secondary organic aerosol (SOA) 2 . The predicted effects of relative humidity on aerosol formation in the $\alpha$-pinene-, $\beta$-pinene-, sabinene-, D3-carene-, and cyclohexene-ozone systems (vol 35, pg 1806, 2001), Environ. Sci. Technol., 35, 1806-1817, doi:10.1021/es011025g, 2001.

Smith, D. F., Kleindienst, T. E., and McIver, C. D.: Primary product distributions from the reaction of $\mathrm{OH}$ with $\mathrm{m}$-, $\mathrm{p}$-xylene, 1,2,4- and 1,3,5-trimethylbenzene, J. Atmos. Chem., 34, 339364, doi:10.1023/A:1006277328628, 1999.

Song, C., Gyawali, M., Zaveri, R. A., Shilling, J. E., and Arnott, W. P.: Light absorption by secondary organic aerosol from alpha-pinene: Effects of oxidants, seed aerosol acidity, and rel- 
ative humidity, J. Geophys. Res.-Atmos., 118, 11741-11749, doi:10.1002/jgrd.50767, 2013.

Sun, Y. L., Zhang, Q., Anastasio, C., and Sun, J.: Insights into secondary organic aerosol formed via aqueous-phase reactions of phenolic compounds based on high resolution mass spectrometry, Atmos. Chem. Phys., 10, 4809-4822, doi:10.5194/acp-104809-2010, 2010.

Surratt, J. D., Murphy, S. M., Kroll, J. H., Ng, N. L., Hildebrandt, L., Sorooshian, A., Szmigielski, R., Vermeylen, R., Maenhaut, W., Claeys, M., Flagan, R. C., and Seinfeld, J. H.: Chemical composition of secondary organic aerosol formed from the photooxidation of isoprene, J. Phys. Chem. A, 110, 9665-9690, doi:10.1021/jp061734m, 2006.

Surratt, J. D., Kroll, J. H., Kleindienst, T. E., Edney, E. O., Claeys, M., Sorooshian, A., Ng, N. L., Offenberg, J. H., Lewandowski, M., Jaoui, M., Flagan, R. C., and Seinfeld, J. H.: Evidence for organosulfates in secondary organic aerosol, Environ. Sci. Technol., 41, 517-527, doi:10.1021/es062081q, 2007.

Surratt, J. D., Chan, A. W. H., Eddingsaas, N. C., Chan, M. N., Loza, C. L., Kwan, A. J., Hersey, S. P., Flagan, R. C., Wennberg, P. O., and Seinfeld, J. H.: Reactive intermediates revealed in secondary organic aerosol formation from isoprene, P. Natl. Aca. Sci. USA, 107, 6640-6645, doi:10.1073/pnas.0911114107, 2010.

Szmigielski, R., Surratt, J. D., Vermeylen, R., Szmigielska, K., Kroll, J. H., Ng, N. L., Murphy, S. M., Sorooshian, A., Seinfeld, J. H., and Claeys, M.: Characterization of 2-methylglyceric acid oligomers in secondary organic aerosol formed from the photooxidation of isoprene using trimethylsilylation and gas chromatography/ion trap mass spectrometry, J. Mass Spectrom., 42, 101-116, doi:10.1002/jms.1146, 2007.

Tan, Y., Carlton, A. G., Seitzinger, S. P., and Turpin, B. J.: SOA from methylglyoxal in clouds and wet aerosols: Measurement and prediction of key products, Atmos. Environ., 44, 5218-5226, doi:10.1016/j.atmosenv.2010.08.045, 2010.

Tan, Y., Lim, Y. B., Altieri, K. E., Seitzinger, S. P., and Turpin, B. J.: Mechanisms leading to oligomers and SOA through aqueous photooxidation: insights from $\mathrm{OH}$ radical oxidation of acetic acid and methylglyoxal, Atmos. Chem. Phys., 12, 801-813, doi:10.5194/acp-12-801-2012, 2012.

Tilgner, A. and Herrmann, H.: Radical-driven carbonyl-to-acid conversion and acid degradation in tropospheric aqueous systems studied by CAPRAM, Atmos. Environ. 44, 5415-5422, doi:10.1016/j.atmosenv.2010.07.050, 2010.

Tolocka, M. P., Jang, M., Ginter, J. M., Cox, F. J., Kamens, R. M., and Johnston, M. V.: Formation of oligomers in secondary organic aerosol, Environ Sci. Technol., 38, 1428-1434, doi:10.1021/es035030r, 2004.

Tuazon, E. C., MacLeod, H., Atkinson, R., and Carter, W. P. L.: $\alpha-$ dicarbonyl yields from the $\mathrm{NO}_{x}$-air photooxidations of a series of aromatic hydrocarbons in air, Environ. Sci. Technol., 20, $383-$ 387, doi:10.1021/es00146a010, 1986.
Virtanen, A., Joutsensaari, J., Koop, T., Kannosto, J., Yli-Pirila, P., Leskinen, J., Makela, J. M., Holopainen, J. K., Poschl, U., Kulmala, M., Worsnop, D. R., and Laaksonen, A.: An amorphous solid state of biogenic secondary organic aerosol particles, Nature, 467, 824-827, doi:10.1038/nature09455, 2010.

Waxman, E. M., Elm, J., Kurten, T., Mikkelsen, K. V., Ziemann, P. J., and Vokamer, R.: Glyoxal and Methylglyoxal Setschenow Salting Constants in Sulfate, Nitrate, and Chloride Solutions: Measurements and Gibbs Energies, Environ. Sci. Technol., 49, 11500-11508, doi:10.1021/acs.est.5b02782, 2015.

Wyche, K. P., Monks, P. S., Ellis, A. M., Cordell, R. L., Parker, A. E., Whyte, C., Metzger, A., Dommen, J., Duplissy, J., Prevot, A. S. H., Baltensperger, U., Rickard, A. R., and Wulfert, F.: Gas phase precursors to anthropogenic secondary organic aerosol: detailed observations of 1,3,5-trimethylbenzene photooxidation, Atmos. Chem. Phys., 9, 635-665, doi:10.5194/acp-9-635-2009, 2009.

Yasmeen, F., Sauret, N., Gal, J. F., Maria, P. C., Massi, L., Maenhaut, W., and Claeys, M.: Characterization of oligomers from methylglyoxal under dark conditions: a pathway to produce secondary organic aerosol through cloud processing during nighttime, Atmo. Chem. Phys., 10, 3803-3812, doi:10.5194/acp-103803-2010, 2010.

Yu, J. Z., Jeffries, H. E., and Sexton, K. G.: Atmospheric photooxidation of alkylbenzenes -I. Carbonyl product analyses, Atmos. Environ., 31, 2261-2280, doi:10.1016/S1352-2310(97)00011-3, 1997.

Zahardis, J., LaFranchi, B. W., and Petrucci, G. A.: Photoelectron resonance capture ionization-aerosol mass spectrometry of the ozonolysis products of oleic acid particles: Direct measure of higher molecular weight oxygenates, J. Geophys. Res.-Atmos., 110, 1-10, doi:10.1029/2004jd005336, 2005.

Zappoli, S., Andracchio, A., Fuzzi, S., Facchini, M. C., Gelencser, A., Kiss, G., Krivacsy, Z., Molnar, A., Meszaros, E., Hansson, H C., Rosman, K., and Zebuhr, Y.: Inorganic, organic and macromolecular components of fine aerosol in different areas of Europe in relation to their water solubility, Atmos. Environ., 33, 2733 2743, doi:10.1016/s1352-2310(98)00362-8, 1999.

Zhao, J., Levitt, N. P., Zhang, R. Y., and Chen, J. M.: Heterogeneous reactions of methylglyoxal in acidic media: Implications for secondary organic aerosol formation, Environ. Sci. Technol., 40, 7682-7687, doi:10.1021/es060610k, 2006.

Ziemann, P. J.: Atmpsheric chmeistry Phase matters for aerosols, Nature, 467, 797-798, 2010.

Zuend, A., Marcolli, C., Peter, T., and Seinfeld, J. H.: Computation of liquid-liquid equilibria and phase stabilities: implications for RH-dependent gas/particle partitioning of organic-inorganic aerosols, Atmos. Chem. Phys., 10, 7795-7820, doi:10.5194/acp10-7795-2010, 2010. 